\title{
Scribal and Commentary Traditions at the Dawn of Print: The Manuscripts of the Near Eastern School of Theology as an Archive of the Early Nahḍa
}

\author{
Salam Rassi \\ Faculty of History, University of Oxford, Oxford, United Kingdom \\ salam.rassi@history.ox.ac.uk
}

\begin{abstract}
This article focuses on the Arabic manuscript collection of the Near Eastern School of Theology (NEST). The NEST library contains several manuscripts that were donated, copied, or read by important Christian-born intellectuals of the nahda. Given these men's role in the emergence of modern publishing in the Middle East, I examine the intersections between their scribal and printing activities. I also discuss works of grammar, logic, and rhetoric in the NEST's collection. Most of these are by late medieval and early modern authors and contain extensive commentaries and glosses. This commentary culture was a key site of learning throughout the early modern Ottoman Empire and endured among Christian as well as Muslim intellectuals of the nahda movement. The persistence of these scribal and intellectual traditions reveals a longue durée of Islamicate scholarly traditions that is only beginning to be understood by historians of Arab modernity.
\end{abstract}

\section{Keywords}

printing - manuscripts - commentaries - Buțrus al-Bustānī - Nāṣîf al-Yāzijī - Fāris al-Shidyāq 


\section{Introduction}

Historians of the Arab nahda have commonly understood the movement in terms of ruptures and discontinuities. ${ }^{1}$ On this scheme, an important feature of Arab modernity was a move away from scribal practice in favour of the printing press and a vogue for textual criticism that conformed to European standards of philological and editorial rigour. ${ }^{2}$ Alongside the growth of the printing press a "Standard Arabic" emerged which was shorn of regional vernacularisms and sectarian signifiers, cultivated by Christian-born intellectuals seeking to negotiate a shared cultural space within a predominantly Muslim Ottoman polity. ${ }^{3}$ I do not wish to deny or diminish the importance of new forms of knowledge production that emerged in the nineteenth century. Rather, my aim in this article is to understand these aspects of modernity — namely, the growth of print media and the standardisation of language - by considering their continuities and overlaps with earlier models of scholarly praxis. By moving away from paradigms of rupture, I show how recent scholarship in manuscript studies and Islamicate intellectual history can help us to better understand the thoughtworld of many of the writers who participated in the construction of Arab

1 For critical engagements with salient nahḍawi themes of "reform" (iṣlāh), "progress" (taqaddum), and "civilisation" (hadāara), see, for example, Albert Hourani, Arabic Thought in the Liberal Age, 1798-1939 (London: Oxford University Press, 1962); Tarek El-Ariss, Trials of Arab Modernity: Literary Affects and the New Political (New York: Fordham University Press, 2013); Stephen Sheehi, "Towards a Critical Theory of Al-Nahdah: Epistemology, Ideology and Capital," Journal of Arabic Literature 43, no. 2-3 (2012): 269-98; Peter Hill, Utopia and Civilisation in the Arab Nahda (Cambridge: Cambridge University Press, 2020).

2 See in particular studies on the famous Būlāq press in Cairo such as Fawzi M. Tadrus, Printing in the Arab World with Emphasis on the Bülāq Press in Egypt (Doha: Faculty of Humanities and Social Sciences, University of Qatar, 1982) and others cited in Hala Auji, Printing Arab Modernity: Book Culture and the American Press in Nineteenth-Century Beirut (Leiden: Brill, 2016), 8, fn. 29. In the context of early modern Europe, the idea that the age of print signalled a seismic and permanent shift away from scribal culture is most notable in Elizabeth L. Eisenstein, The Printing Press as an Agent of Change: Communications and Cultural Transformations in Early Modern Europe (Cambridge: Cambridge University Press, 1980), 163-208.

3 Yasir Suleiman, The Arabic Language and National Identity: A Study in Ideology (Edinburgh: Edinburgh University Press, 2003); Abdulrazzak Patel, The Arab Nahdah: The Making of the Intellectual and Humanist Movement (Edinburgh: Edinburgh University Press, 2013), 36-126; Rana Issa, "Rakākah and the Petit Quarrel of 1871: Christian Authors and the Competition over Arabic," in Language, Politics and Society in the Middle East: Essays in Honour of Yasir Suleiman, eds. Abeer Al-Najjar and Yonatan Mendel (Edinburgh: Edinburgh University Press, 2018), 148-64; Geoffrey Roper, "Arabic Printing in Malta 1825-1845: Its History and Its Place in the Development of Print Culture in the Arab Middle East" (PhD diss., University of Durham, 1988), 139-41. 
modernity. One important avenue for the study of these continuities is the history of Middle Eastern library collections, many of which are now beginning to be understood in terms of their owners and collectors and not simply as static repositories of knowledge. 4

My case study is a collection of Arabic manuscripts housed in the Near East School of Theology (Kulliyat al-Lähüt li-l-Sharq al-Awșat, henceforth NEST) all of which have been digitised and made available online by the Hill Museum and Manuscript Library. ${ }^{5}$ The school began life as the seminary wing of the American Board of Commissioners for Foreign Missions (АвСғM) in Syria, headed by the American protestant missionaries and Arabists Eli Smith (18011857), Cornelius Van Alen Van Dyck (1818-1895), and others. Initially located in the village of 'Abayh, the seminary later merged with the Syrian Protestant College (now the American University of Beirut, AUB), though the two have long since parted ways. ${ }^{6}$ Among the many manuscripts housed in this collection are drafts of the Arabic Bible translation overseen by Smith and later Van Dyck, and contributed to by Buțrus al-Bustānī (1819-1883), Nāṣîf al-Yāzijī (180o-1871), and other well-known figures of the nahda. ${ }^{7}$ Begun in 1820 , early additions to the collection tended to be outside gifts or commissions from professional scribes, namely members of the al-Shidyāq family and Nāṣîf al-Yāzijī. ${ }^{8}$ A further core of manuscripts comes from a sizeable acquisition made by the Syrian Society for Arts and Sciences (ssas), founded by Nāṣîf al-Yāzijī, Buṭrus

4 See, for example, Ahmed El Shamsy, "Islamic Book Culture through the Lens of Two Private Libraries, 1850-1940," Intellectual History of the Islamicate World 4, no. 1-2 (2016): 61-81.

5 These manuscripts can be viewed in HMML's Virtual Reading Room (https://www.vhmml .org/) by entering "NEST" in the "HMML project number" field, followed by shelfmark (if known), e.g., "NEST AB 17."

6 For a history of the seminary, see Abdul Latif Tibawi, "The Genesis and Early History of the Syrian Protestant College," Middle East Journal 21, no. 1 (1967): 1-15; idem, American Interests in Syria, 1800-1901: A Study of Educational, Literary and Religious Work (Oxford: Clarendon Press, 1966); George F. Sabra, Truth and Service: A History of the Near East School of Theology (Beirut: Librairie Antoine, 2009). It is also important to note that the SPC was never technically part of the Syria Mission, though its founding was in keeping with the Mission's aims; see Tibawi, American Interests, 162.

7 NEST MS AC 36-1-26; see James W. Pollack and Rachel Pollock, "Catalogue of Manuscripts of the Library of the Near Eastern School of Theology," The Near East School of Theology Theological Review 4, no. 1-2 [1981]:1-121, $\mathrm{n}^{\circ}$ 146. On this translation enterprise, see Ghassan Khalaf, "Tarjamat al-kitāb al-muqaddas ilā al-'arabiyya wa-l-mu'aththirāt," in Translating the Bible into Arabic: Historical, Text-Critical, and Literary Aspects, eds. Sara Binay and Stefan Leder (Beirut: Ergon Verlag, 2012), 7-24; David D. Grafton, "A Critical Investigation into the Manuscripts of the 'So-Called' Van Dyck Bible," Cairo Journal of Theology 2 (2015): 56-64.

8 Pollack and Pollack, Catalogue, v. 
al-Bustānī, and Mīkhā̄ìl Mishāqa (180o-1888) in $1847 .{ }^{9}$ Following the disbandment of the SSAC in 1852, 206 of these manuscripts passed into the care of Eli Smith and thereafter to the Syrian Protestant College, forming the nucleus of the current manuscript collection of AUв. ${ }^{10}$ Ever since the split between AUB and the seminary, the permanent collections of AUB and NEST remain separate though inextricably linked by a common Arab Protestant heritage.

Given that so many of the manuscripts in the NEST collection were copied, owned, and donated by the nahda's leading lights, the collection represents a critical intersection between print and scribal cultures. In addition to the scribal practices surrounding their production, the actual contents of these manuscripts shed new light on the intellectual activities and strategies of key nahda figures. For these reasons, I have placed the NEST collection at the centre of my study.

Based on material from the NEST collection and elsewhere, I wish to make two points where the nahda is concerned. The first pertains to codicology and the history of the book. The rich material preserved in NEST suggests that manuscript production in the early nineteenth century reflected a critical preoccupation with accuracy and detail best understood in its scribal context. For Arab Christians living in Ottoman lands in the first half of the nineteenth century, clarity and editorial exactitude were not simply by-products of an emergent Arab nationalism or foreign missionary enterprise. ${ }^{11}$ Rather, such tendencies were already present in the scribal culture of the day. This was the case among Christian scribal families who had worked as notaries and bureaucrats for the Ottoman nobility prior to entering the service of American missionaries. To be sure, the exposure of nahda intellectuals to missionary presses contributed to their transitioning from local scribes to "cultural entrepreneurs who made a living out of writing original works in Arabic."12 However, as I seek to demonstrate, scribal conventions were not immediately forgotten with the introduction of modern print media. As recent historians of print have

9 Anonymous, "Gesellschaft der Künste und Wissenschaften in Beirut," Zeitschrift der Deutschen Morgenländischen Gesellschaft 2 (1848):378-88, here 382-3; Edward E. Salisbury, "II. Syrian Society of Arts and Sciences," Journal of the American Oriental Society 3 (1853): 477-86.

10 Kaoukab Chebaro and Samar El Mikati El Kaissi, "Manuscript Ownership and Readership at the American University of Beirut at the Turn of the Twentieth Century," in Manuscripts, Politics and Oriental Studies: Life and Collections of Johann Gottfried Wetzstein (1815-1905) in Context, eds. Boris Liebrenz and Christoph Rauch (Leiden: Brill, 2019), 268.

11 For debates concerning the impact of missionary influence on the nahda, see Tibawi, American Interests; David D. Grafton, The Contested Origins of the 1865 Arabic Bible (Leiden: Brill, 2016).

12 Issa, "Rakāka," 152. 
observed, Arab intellectuals working as printers in the 1800 s experimented with decorative styles and literary conventions that were strongly-and intentionally—reminiscent of scribal traditions. ${ }^{13}$ These traditions are readily discoverable in the NEST collection, which contains several manuscripts copied by figures who excelled as scribes as well as printers and litterateurs.

My second argument is a broader intellectual-historical one. The manuscripts from NEST with which I am chiefly concerned are grammatical and logical in content. The collection's modern catalogue lists them alongside works of prosody, poetry, and lexicography. ${ }^{14}$ Much has been said about the lexicographical turn in the nineteenth century and the use of dictionaries by nahda writers as a civilisational index. ${ }^{15}$ As for other areas of learning, Marwa Elshakry has discussed the ways in which American missionaries promoted Enlightenment notions of natural science and philosophy in the Ottoman Levant as part of an Evangelical modernity. ${ }^{16}$ But when it came to Arabic grammar and lexicography, these same missionaries were invariably reliant on local knowledge and expertise. What, then, was the tradition of Arabic grammar that these missionaries first encountered? American and European missionaries tended to distinguish between "Western knowledge" and the linguistic sciences of the Arabs. Yet such a distinction overlooks the overlapping epistemologies underlying the discipline of Arabic grammar. For by the nineteenth century, the discipline of logic in Ottoman lands was often studied alongside (if not before) grammar. ${ }^{17}$ The site of this tradition was a post-classical genre of commentary and super-commentary, which from the post-Mongol period through to the seventeenth and early twentieth centuries constituted a major

13 Auji, Printing Arabic Modernity, 1-2; Chebaro and El Mikati El Kaissi, "Manuscript Ownership and Readership at AUB."

14 Pollock and Pollock, "Catalogue," 1-19 (Nos 1-110).

15 For constructions of Arab nationhood through lexicography, see Nadia Bou Ali, "Collecting the Nation: Lexicography and National Pedagogy in al-nahda al-arabiyya," in Archives, Museums and Collecting Practices in the Modern Arab World, eds. Sonja Mejcher-Atassi and John Pedro Schwartz (London: Routledge, 2012), 34-56.

16 Marwa Elshakry, "The Gospel of Science and American Evangelism in Late Ottoman Beirut," Past and Present 196, no. 1 (2007): 173-214. On the impact of nineteenth-century Western European notions of science on the visual culture of the nahda, particularly in illustrations in the popular science journal al-Muqtataf (1876-1952), see Hala Auji, "Printed Images in Flux: Examining Scientific Engravings in Nineteenth-Century Arabic Periodicals," in Visuelles Design: Die Journalseite als gestaltete Fläche / Visual Design: The Periodical Page as a Designed Surface, eds. Andreas Beck et al. (Hannover: Wehrhahn Verlag, 2019), 199-236.

17 Khaled El-Rouayheb, The Development of Arabic Logic (1200-1800) (Basel: Schwabe Verlag, 2019), 16-17. 
vehicle of learning in educated Ottoman circles, Muslim and Christian alike. ${ }^{18}$ This late medieval and early modern Ottoman commentary culture is amply reflected in the NEST manuscripts.

In the following sections, I argue that the endurance of both scribal and scholarly traditions among nahda intellectuals reveals the uneven and variegated nature of Arab modernity in the nineteenth century. This continuity is readily discoverable in the NEST collection. By focusing on this repository, I seek to show how Christian-born intellectuals in Mount Lebanon and Beirut remained committed to traditional modes of Ottoman intellectual production. This situation, I contend, rather complicates the idea of the nahda as a period of ruptures.

\section{Situating the NEST Collection: Scribal, Commentary, and Print Cultures on the Eve of the Nahḍa}

Before proceeding, it is important to acknowledge that Arabic printing began not in the Middle East but in Europe. ${ }^{19}$ The earliest Muslim-led printing enterprise in the Ottoman Empire was a moveable Arabic type press established in Istanbul by İbrāhīm Müteferriḳa and active between 1726 and 1742. ${ }^{20}$ However, to truly understand the beginnings of modern publishing in the Middle East, we must look to the Christian communities of the Ottoman levant. In particular, Mount Lebanon was home to Christian communities whose local agency as scribes, intellectuals, and publishers led to an efflorescence of print media in the region throughout the seventeenth and eighteenth centuries. The earliest recorded instance of Arabic printing in the Middle East was at the Maronite

18 On this method of discursive learning in Ottoman medreses, see Khaled El-Rouayheb, Islamic Intellectual History in the Seventeenth Century: Scholarly Currents in the Ottoman Empire and the Maghreb (Cambridge: Cambridge University Press, 2015). Note that by "post-classical" I mean here a specific current of intellectual production that developed throughout much of the Islamicate world between the post-Mongol/Timurid era and the late eighteenth century. I do not employ the term to imply that prior to the nahda there was a period of intellectual decline after a "classical" (viz. pre-Ottoman) period of efflorescence, as has been the case in some past scholarship, on which see Thomas Bauer, "In Search of 'Post-Classical Literature': A Review Article," Mamluk Studies Review 11, no. 1 (2007): 137-67.

19 The earliest extant printed Arabic work is a book of hours (Kitāb al-șalāt al-sawā̄i $)$ produced in Fano, Italy in 1514; see Miroslav Krek, "The Enigma of the First Arabic Book Printed from Movable Type," Journal of Near Eastern Studies 38, no. 3 (1979): 203-12.

20 William J. Watson, "İbrāhīm Müteferriḳa and Turkish Incunabula," Journal of the American Oriental Society 88, no. 3 (1968): 435-41. 
Monastery of St. Anthony in Wādī Qadīshā, where a Karshūnī Psalter was produced in $1610 .{ }^{21} \mathrm{~A}$ further example was the Greek Catholic press of the Monastery of St. John (Mațba'at Dayr Mār Yüḥannā) in Kinshāra, better known as al-Shuwayr. ${ }^{22}$ Established in 1734 and active until 1899, the Shuwayr press produced a number of works that set an important standard for Christian Arabic publishing in the following century.

As will become clearer throughout this article, the domains of scribal, commentary, and print culture in the nineteenth century were intimately connected. By considering the NEST collection as part of this entangled history, my approach departs considerably from that of earlier historians. Influenced by insights from Elizabeth Eisenstein's history of moveable type print, Geoffrey Roper argued that Arabic scribal culture in the nineteenth century was marked by a certain "esotericism" and "obscure style of expression," which tended to view knowledge as a "mystical and secret entity." The adoption of print-based culture, he contends, broke the scribal monopoly on knowledge, contributing to the "demystification of language and literature" and "the revival of the classical heritage."23 At the centre of both Eisenstein's and Roper's approach is the idea that print media catalysed the emergence of a new text-critical awareness among authors and publishers, which in turn facilitated a wider circulation of canonical works. The NEST material, however, rather undermines this technological determinism. Manuscripts from this collection evince not only a longue durée of scribal practice but also blurred boundaries between the roles of scribe, author, and printer.

In addition to scribal continuities, the NEST collection also exhibits points of contact with late medieval and early modern scholarly practices, namely in the areas of grammatical and philosophical commentary. Until relatively recently, much of this tradition was studied through the lens of decline. Carter Findley has viewed the institution of the Ottoman elementary school (kuttäb) in the early nineteenth century as having produced little more than "functional illiterates" prior to Western-inspired educational reforms. This stagnation,

21 Carsten-Michael Walbiner, "Ktōbō d-mazmūrē d-Dawīd malkō wa-nbīyō," in The Beginnings of Printing in the Near and Middle East: Jews, Christians and Muslims, ed. Klaus Kreiser (Wiesbaden: Harrassowitz, 2001), 22.

22 On the Shuwayr press, see Roper and Glass, "The Printing of Arabic Books in the Arab World," 179-81.

23 Geoffrey Roper, "Fāris Al-Shidyāq and the Transition from Scribal to Print Culture in the Middle East," in The Book in the Islamic World: The Written Word and Communication in the Middle East, ed. George N. Atiyeh (New York: SUNY Press, 1995), 209-10. For similar remarks about the esoteric nature of the scribal age, see Eisenstein, The Printing Press, 270. 
according to Findley, was due to "an encrustation of commentaries that had virtually obscured the seminal texts of Islamic learning." ${ }^{24}$ Where grammar is concerned, Geoffrey Roper has described standards in Arabic style and composition just prior to the nahda as convoluted and obscure, particularly in Arab Christian circles, in which a certain stylistic laxity ( rakāka) dominated. This situation, Roper contends, was markedly improved by the codification of "Standard Arabic" through print technology and the production of textbooks and grammars by missionary presses. ${ }^{25}$ However, a more recent generation of scholars has undermined the "theoretical and paradigmatic bases" of Ottoman decline. ${ }^{26}$ In the area of intellectual history, scholars have revealed the aforementioned commentary culture to have been an critical site of engagement with canonical texts. ${ }^{27}$

With the rise of print media in the Middle East, however, these commentaries and glosses were eventually eclipsed by a new canon of earlier, mostly Abbasid-era works that constituted the "Islamic Classics." 28 Yet it is this late medieval and early modern tradition of grammar and logic that is most represented in the NEST collection. A close examination of this repository reveals an entangled and interconfessional tradition of grammatical pedagogy during the early phase of the nahda. The presence of this corpus of post-classical works suggests that the emergence of new canons did not fully displace old ones. Rather, early nahda thinkers were well-acquainted with the legacy of late medieval and early modern Islamic thinkers, whose works they not only read but also copied and placed in the possession of American missionaries who sought key texts on Arabic grammar and logic.

24 Findley, "Knowledge and Education," 132f.

25 Roper, "Fāris al-Shidyāq and the Transition," 217.

26 For a masterful survey of twenty-five years of literature challenging the decline thesis, see Dana Sajdi, "Decline, its Discontents and Ottoman Cultural History: By Way of Introduction," in Ottoman Tulips, Ottoman Coffee: Leisure and Lifestyle in the Eighteenth Century, ed. Dana Sajdi (London: I.B. Tauris, 2007), 1-40 (quotation on 3). More recent interventions have been discussed above.

27 Robert Wisnovsky, "The Nature and Scope of Arabic Philosophical Commentary in PostClassical (ca. 1100-1900 AD) Islamic Intellectual History," in Philosophy, Science and Exegesis in Greek, Arabic and Latin Commentaries, eds. Peter Adamson et al., 2 vols. (London: Institute of Classical Studies, 2004), 2:149-91; Asad Q. Ahmed, "Post-Classical Philosophical Commentaries/Glosses: Innovation in the Margins," Oriens 41 (2013): $317-48$.

28 Ahmed El Shamsy, Rediscovering the Islamic Classics: How Editors and Print Culture Transformed an Intellectual Tradition (Princeton: Princeton University Press, 2020). See also Khaled El-Rouayheb, "Rethinking the Canons of Islamic Intellectual History," in Studying the Near and Middle East at the Institute for Advanced Study, Princeton, 1935-2018, ed. Sabine Schmidtke (Piscataway [NJ]: Gorgias Press, 2018), 154-63. 


\section{Embedded Scribal Traditions: The Case of the Shidyāq Family and Nāṣîf al-Yāzijī}

Historians have long acknowledged that the first generation of nahda thinkers were involved in scribal production. ${ }^{29}$ Perhaps the best-known figures in this regard were members of the Shidyāq family and Nāṣîf al-Yāzijī, whose scribal activities will now be discussed. This section will demonstrate the embeddedness of manuscript-based culture in the intellectual life of the early nahda, with special reference to the NEST collection.

To fully appreciate this embeddedness, we must first look to earlier printing traditions in the Middle East. As has already been mentioned, moveable type print was already in use at the Shuwayr press. Hala Auji has recently discussed this press's frequent use of scribal elements such as ornamental boarders and catchwords, of which Eli Smith and the Syria Mission took note when deciding how to design the inaugural editions of the American Missionary Press's (AMP) (on which more below). ${ }^{30}$ The monastery of al-Shuwayr also housed a manuscript workshop, and so it is little wonder to find such scribal entanglements in its print culture. ${ }^{31}$ In fact, scribal-print exchanges could also travel in the other direction: a manuscript of al-Qāsim ibn 'Alī al-Ḥārīî̉s (d. 1122) metrical grammar contains a numbered table of contents (fihrisa) in its flyleaf - a feature commonly associated with European printing conventions intended to make a work more accessible. ${ }^{32}$ The table of contents and pagination were produced

29 Arthur J. Arberry, "Fresh Light on Ahmad Faris al-Shidyaq," Islamic Culture 26, no. 1 (1952): 156-64; Muḥammad Aḥmad Khalaf Allah, Aḥmad Fāris al-Shidyāq wa-ārāuhu al-lughawiyya wa-l-adabiyya (Cairo: Jāmi'at al-Duwal al-'Arabiyya. Ma'had al-Dirāsāt al-'Arabiyya al-Lughawiyya, 1955), 84; 'Imād al-Ṣulḥ, Aḥmad Fāris: āthāruhu wa-'așruhu. 2nd ed. (Beirut: Sharikat al-Mațbū'āt li-l-Tawzī‘ wa-l-Nashr, 1987), 251-52; Carter Vaughn Findley, "Knowledge and Education in the Modern Middle East: A Comparative View," in The Modern Economic and Social History of the Middle East in its World Context, ed. Georges Sabagh (Cambridge: Cambridge University Press, 1989), 132; Roper, "Ahmmad Fāris al-Shidyāq and the Transition."

$30 \quad$ Auji, Printing Arabic Modernity, 52.

31 On the reading and copying of manuscripts at al-Shuwayr, see Carsten-Michael Walbiner, "Monastic Reading and Learning in Eighteenth-Century Bilād al-Šām: Some Evidence from the Monastery of al-Šuwayr (Mount Lebanon)," Arabica 51, no. 4 (2004): 462-77.

32 While lists of contents and indices (or "calendars") were a feature of manuscript culture in the medieval Latin West, self-identifying tables of contents, particularly those that contained page numbers, became more prevalent in early modern European print; see Mary A. Rouse and Richard H. Rouse, "La naissance des index," in Histoire de l'édition française vol. 1: Le livre conquérant: du Moyen âge au milieu du XVII e siècle, ed. Henri-Jean Martin and Roger Chartier (Paris: Promodis, 199o), 79. In medieval and early modern Arabic literary traditions, one sometimes finds a list of contents in the author's preface. 
by the manuscript's owner, one Jibrāîl ibn Niqūlā al-Ḥimṣī al-Dimashqī, when he purchased it in 1794 whilst in al-Shuwayr. ${ }^{33}$

However, the intersection between manuscript and print was not just visual or paratextual; scribal conventions were also applied to the editing of printed works. Islam Dayeh has recently revealed how the scribal practices of tașhịh ("correction") and muqābala ("collation") informed editorial activities in nineteenth-century Cairo. The early editions of the Būlāq Press (established in 1820) saw the combining of existing scribal methods with lithography. In effect, the correctors (mușahhihün) at the press made use of manuscriptcentred textual criticism to produce books derived from reliably transmitted exemplars. ${ }^{34}$

These practices had deep roots in medieval and early modern Islamic scribal and text-critical traditions. ${ }^{35}$ As a result of contact through bureaucratic and educational institutions in the Ottoman Levant, such methods gradually made inroads into Christian elite circles. Members of this elite included Yūsuf al-Shidyāq (d. 1820) and his sons As'ad (d. 1830), Fāris (later Aḥmad Fāris upon his conversion to Islam), and Țannūs (1791-1861). The Shidyāqs had a history of service to the Muslim, Christian, and Druze nobility of Mount Lebanon and the Biqā' reaching back to the seventeenth century as scribes, notaries, tax collectors, property agents, and tutors. ${ }^{36}$ Manșūr al-Shidyāq left his native Kisrwān to enter the service of the Shīīi Harfūsh emirs of Bacalbak, then moved

However, this is rarely, if ever, numbered or foliated; see Adam Gacek, Arabic Manuscripts: A Vademecum for Readers (Leiden: Brill, 2009), 259.

33 This manuscript is now part of the collection of the Lebanese Maronite Missionary Order, Jounieh, digitised and accessible via the HMML Virtual Reading Room (vhmml.org), project number LMMO 156. The owner indicates his composition of the table of contents in a

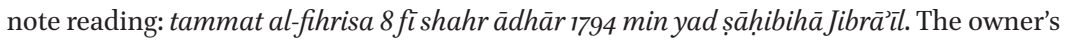
note of purchase, also dated 1794, is located on p. 209. I am grateful to Feras Krimsti for bringing this manuscript to my attention.

34 Islam Dayeh, "From Tashīḥ to Tahqiīq: Toward a History of the Arabic Critical Edition," Philological Encounters 4 (2019): 269-72. On the role of the musahhih, see also El Shamsy, Rediscovering the Islamic Classics, 79-82. For the role of the corrector in early modern European book production, see Anthony Grafton, Inky Fingers: The Making of Books in Early Modern Europe (Cambridge [MA]: Belknap, 2020), ch. 1.

35 In the domain of pre-modern hadìth scholarship, processes of taṣhịh and muqābala were employed in an authoritative edition of the Sahịh Bukhārī by the Hanbalī jurist Sharaf al-Dīn al-Yūnīnī (d. 1301), and the grammarian Ibn Mālik (d. 1274). In 1893, a printed edition of the work was commissioned by 'Abd al-Hamid II; Dayeh, "From Tașhịh to Taḥqüq," 277 f.

36 The following information about the history of the Shidyāq family is taken from Țannūs's own account in his Kitāb akhbār al-a'yān fì jabal Lubnān, ed. Fu’ād E. Bustānī, 2 vols. (Beirut: Publications de l'Université Libanaise, 1970), 1:110-21; Kamal Salibi, Maronite Historians of Mediceval Lebanon (Beirut: American University of Beirut, 1959), 161-66. 
to Hazmiyya and later 'Ashqūt to serve the powerful Maronite Shihāb clan. His son, Yūsuf, would continue in the service of the Shihāb emirs, as would Yūsuf's son, Ṭannūs, who worked as a clerk and tax collector before embarking on a career as a copyist and Arabic teacher in the service of American Protestant missionaries. Țannūs's younger brothers, As'ad (1797-1830) and Fāris (later Ahmad Fāris upon his conversion to Islam), would also enter the service of American Protestants as copyists, correctors, and teachers. ${ }^{37}$

Yūsuf, Țannūs, As'ad, and Fāris are all examples of Christian-born figures who inhabited both Christian and Muslim educated milieus. In their early years, Țannūs, As'ad, and Fāris each attended the Maronite Seminary of 'Ayn Waraqa, an institution steeped in the ideals of post-Tridentine Catholicism, where the Shidyāq brothers would no doubt have been exposed to a Maronite scribal culture. ${ }^{38}$ Nevertheless, their father, having worked for years as a private secretary for Muslim and Christian nobility, was intimately familiar with Arabic scribal traditions that cut across confessional boundaries.

This tradition was one that privileged exactitude and diligence in the art of copying. For generations prior to the nineteenth century, Arabic scribes often copied manuscripts by perusing more than one exemplar to ensure that their copy had been completed on the best authorities. The practice is thought to have its origins in Islamic hadith-writing, in which the scribe signals that the text was suitable for transmission, though it was quickly taken up in other genres. ${ }^{39}$ Arabic scribes often indicated whether their copies had been corrected or checked against others through a careful process of collation. In some cases, collation (muqābala, mu'ārada) and correction (tașhịh) were carried out by someone other than the scribe. ${ }^{40}$ Such conventions are detectable in one NEST manuscript containing a grammar by Abū Ḥayyān al-Gharnațī

37 On As'ad's life, see Ussama Samir Makdisi, Artillery of Heaven: American Missionaries and the Failed Conversion of the Middle East (Ithaca: Cornell University Press, 2008), 103-37.

38 For the syllabus of the 'Ayn Waraqa school, which included the art of manuscript copying, see Nāșir Jumayyil, Les échanges culturels entre les Maronites et l'Europe: du Collège maronite de Rome (1584) au Collège de Ayn-Warqa (1789), 2 vols. (Beirut: n.p., 1984), 2:101114; Makdisi, Artillery of Heaven, 79.

39 Rosemarie Quiring-Zoche, "How al-Buhārī's Șaḥ̄ḥ was Edited in the Middle Ages: 'Alī al-Yūnīnī and his Rumūz," Bulletin d'études orientales 50 (1998): 191-222; Gacek, Arabic Manuscripts, 65-69. For this method of textual transmission in other literary genres, see Matthew L. Keegan, "Commentators, Collators, and Copyists: Interpreting Manuscript Variation in the Exordium of Al-Harīrī's Maqāmāt," in Arabic Humanities, Islamic Thought, eds. Joseph E. Lowry and Shawkat Toorawa (Leiden: Brill, 2017), 295-316.

40 Rosemarie Quiring-Zoche, "The Colophon in Arabic Manuscripts: A Phenomenon without a Name," Journal of Islamic Manuscripts 4, no. 1 (2013): 73. 


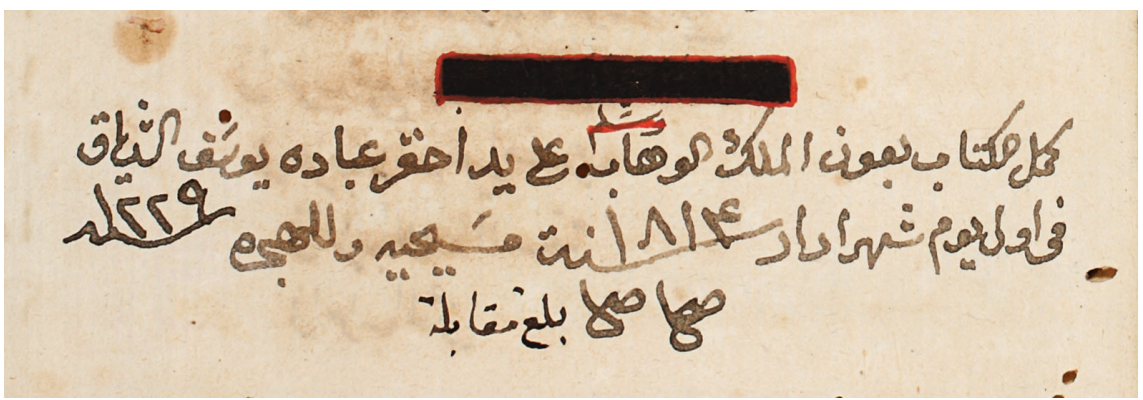

FIGURE 1 NEST AB 5: Colophon, with collation and correction notes, by Yūsuf al-Shidyāq, dated $1229 / 1814$

(d. 1344), copied by Yūsuf in 1814 (see Fig. 1). ${ }^{41}$ Using the customary ص mark (șaḥha), Yūsuf indicates that his copy had been corrected. At the end of the colophon, we encounter the collation statement balagha muqābalatan, in a different hand, possibly by one of his sons, As'ad or Tannūs, based on script comparison. ${ }^{42}$

It was this tradition of scribal labour that informed much of Fāris al-Shidyāq's early activities. Like his brothers, he also began as a professional scribe, having produced a copy of Ḥaydar al-Shihābī's family chronicle among his earliest commissions. ${ }^{43}$ Although no manuscripts copied by al-Shidyāq are held in the NEST collection, we do find one copy of a work by Muhammad al-Fayyūmī (d. ca. 1368) containing a readership statement by him dated 1834, written in an elegant, calligraphic hand (see Fig. 2). It is interesting to note that al-Fayyūmı̄'s treatise, entitled al-Mișbāh al-munīr ("The Luminous Lamp"), is a lexicon of legal definitions. Al-Shidyāq's interest in this manuscript appears to be in line with his interest in lexicography—a subject that occupied the minds of so many Arab intellectuals throughout the nineteenth century. ${ }^{44}$

Al-Shidyāq was also known to have taken an active interest in the circulation and preservation of Arabic manuscripts in Europe, especially during

$41 \quad$ NEST AB 5 (undated), p. 194.

42 For examples of the abbreviation $ص$ and common collation statements such as bagha muqābalatan, see Gacek, Arabic Manuscripts, 4, 66-68. Another manuscript copied by Yūsuf al-Shidyāq, NEST AB 12 (before 1825 AD), containing Harīrìs Maqāmāt and Nīqūlā Ṣāigh's Rayhānāt al-arwāḥ, has a similarly worded colophon, though without collation statements; see Pollock and Pollock, Catalogue, 4.

43 Roper, "Fāris al-Shidyāq and the Transition," 210.

44 Abou Ali, "Collecting the Nation." 


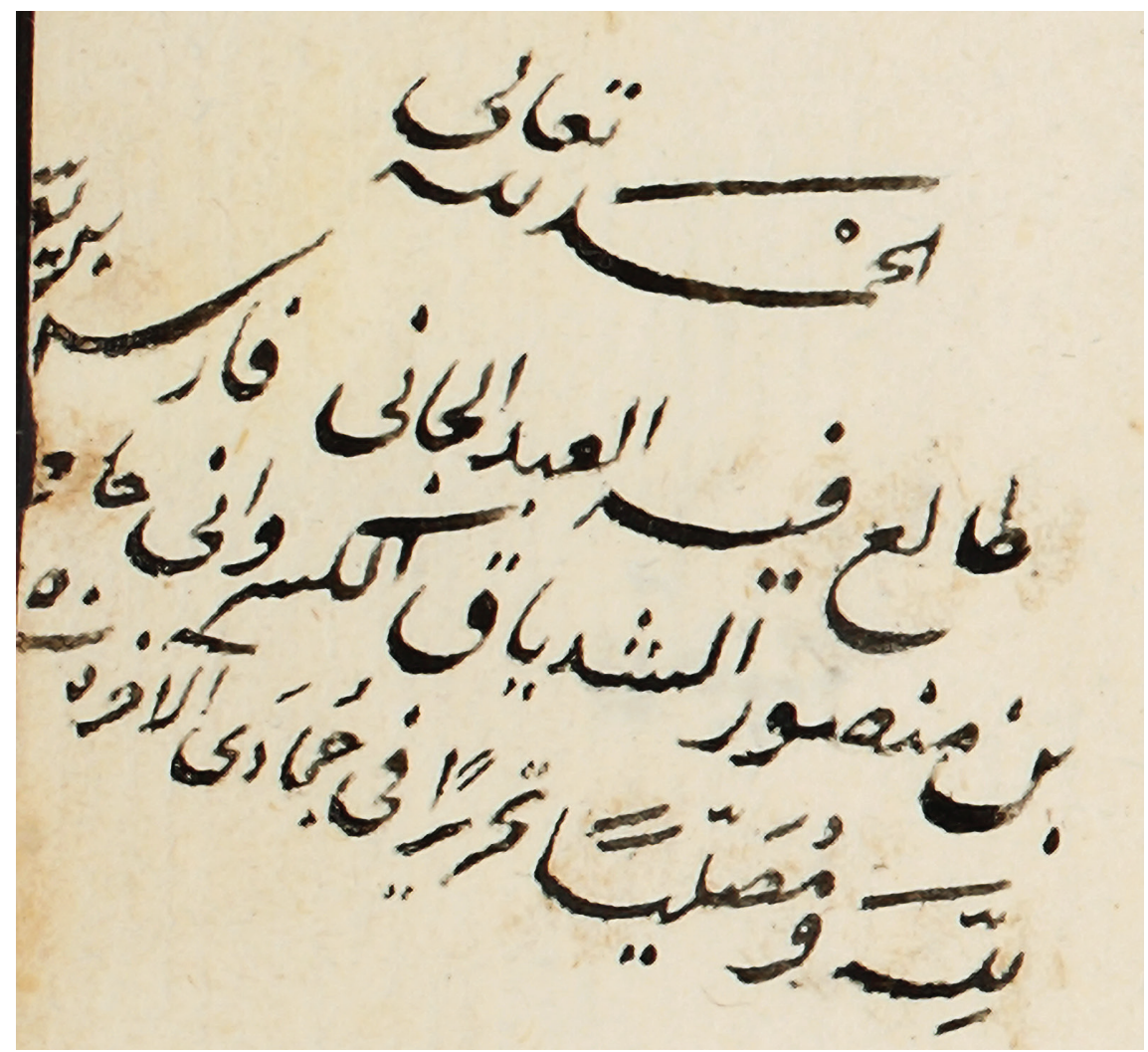

FIGURE 2 Readership statement by Fāris al-Shidyāq, dated 125o/1834

his seven-year stay in England (1848-1855) ${ }^{45}$ Yet in addition to reading manuscripts, Aḥmad Fāris was also active in copying classical works of Arabic literature, having produced a copy of Zawzānī's commentary on the Mu'allaqāt ("Suspended Odes") during his stay in Egypt between 1825 and 1835 and a copy of Ma'arrī's Saqt al-zand ("The Falling Spark of Tinder") in $1844 .{ }^{46}$ Even in his earliest printed compositions, al-Shidyāq wrote about the importance of maintaining high aesthetic and technical standards when practicing the scribal craft. This is particularly evident in his Muhāwara unsiyya fi al-lughatayn

45 Geoffrey Roper, "Aḥmad Fāris al-Shidyāq and the Libraries of Europe and the Ottoman Empire," Libraries \& Culture 33, no. 3 (1998): 233-48.

46 For al-Shidyāq's manuscript of the Mu'allaqāt, see John Macdonald, Catalogue of Oriental Manuscripts: III. Arabic-15o (Leeds: The University of Leeds, Department of Semitic Languages \& Literatures, [1959]), 28, no. 128 (1833 AD), cited in Roper, "Fāris al-Shidyāq and the Transition," 211. The manuscript of Macarri’s Saqt al-zand is now Cambridge, University Library, Or. 2215. 
al-inklizinya wa-l-arabiyya ("A Familiar Dialogue concerning the Languages of English and Arabic"), a pedagogical dialogue on the Arabic language cowritten by the English churchman and orientalist George Percy Badger and printed in Malta in 1836. Here, al-Shidyāq introduces several technical terms for manuscript-writing and bookmaking and discusses which types of pens and inks are best suited to writing the Arabic language. ${ }^{47}$ Furthermore, in his famous semi-biographical satire entitled al-Sāq 'alā al-sāq ("Leg Over Leg"), published in 1855, al-Shidyāq describes how the people of the region of his protagonist, Fāryāq, "gave precedence to good writing over anything else the hand might make." But despite this, the local authorities "employed as scribes only those whose writing was ugly to the eye and whose words were disgusting to good taste." 48

At first blush, Fāris al-Shidyāq's admiration for manuscript culture appears little more than an antiquarian's nostalgia for a tradition in decline. Indeed, for all his reverence of the scribal art, al-Shidyāq was a great champion of print culture who recognised its usefulness for producing classical Arabic texts, having conceived of the first edition of his al-Sāq 'ala al-sāq as a printed book. ${ }^{49}$ Nowhere, however, does he explicitly state that print was the only means of establishing sound texts. Given his family background, it is likelier that al-Shidyāq was aware of the philological potential of scribal practices. As we have already observed from a manuscript copied by his father, the scribal tradition that had come down to him was one that valued precision, collation, and correction-skills also prized by the various European and American missionaries for whom the Shidyāqs worked as translators and correctors. ${ }^{0}$ These scribal conventions are discoverable in the scribal output of Fāris's older brothers, As'ad and Țannūs. We find such an example in Nest Aв 66 (see Fig. 3), a manuscript copied by As'ad with the help of Tannūs, containing two grammatical works by Jirmānūs Farhāa $\left(1670-173^{2}\right)$ entitled Bāb al-i'rāb 'an lughat al-a'rāb ("Introduction to the Eloquent Expression of the Arabic Language")

47 George Percy Badger and Fāris Shidyāq, al-Muḥāwara al-unsiyya fì al-lughatayn al-inklizizyya wa-l-arabiyya (Malta, 1849), 134.

48 Aḥmad Fāris al-Shidyāq, Leg over Leg. Or the Turtle in the Tree: Concerning the Färiyāq, What Manner of Creature Might He Be, eds. Humphrey Davies and Michael Cooperson, 2 vols. (New York: New York University Press, 2013), 1:6o (text), 61 (trans.).

49 Roper, "Fāris al-Shidyāq and the Transition"; Kamran Rastegar, Literary Modernity between the Middle East and Europe: Textual Transactions in Nineteenth-Century Arabic, English, and Persian Literatures (London: Routledge, 2007), 108.

50 On missionary anxieties about reliable and accurate Biblical translations and revisions, see Sara Binay, "Revision of the Manuscripts of the So-Called Smith-Van Dyck Bible," in Translating the Bible into Arabic: Historical, Text Critical and Literary Aspects, ed. Sara Binay (Beirut: Orient-Institut, 2012), 76-84; Tibawi, American Interests, 120-23. 


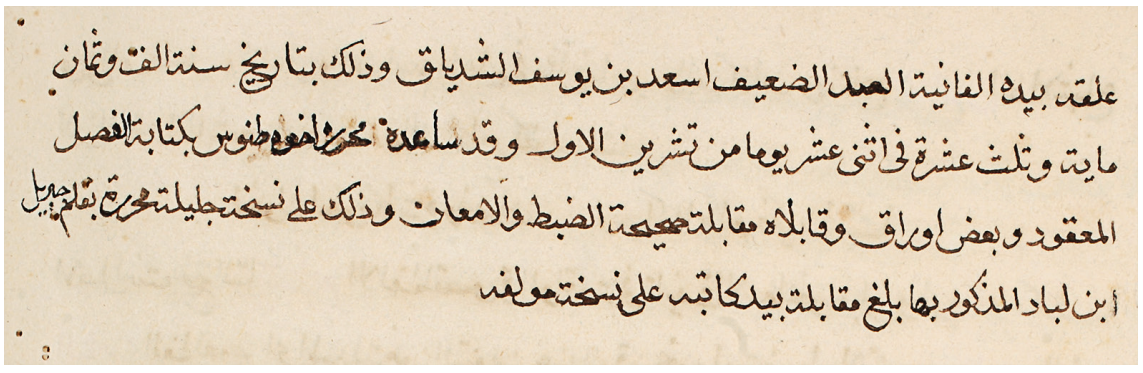

FIGURE 3 NEST AB 66: Colophon by As‘ad al-Shidyāq, dated 1813

and al-Faṣl al-ma'qūd fì ma'ānı̄ 'awāmil al-i'rāb ("The Agreed Conclusion Concerning the Particles of Arabic Grammar").

Incidentally, Fāris al-Shidyāq's first printed commission was also a work by Farḥāt: an editio princeps of his grammar, Bậth al-mațālib fi al-lugha al-arabiyya, published in 1836 in Malta. ${ }^{51}$ But whereas Fāris provides no information about his editorial technique, his brother As'ad tells us the following in his colophon to NEST AB 66:

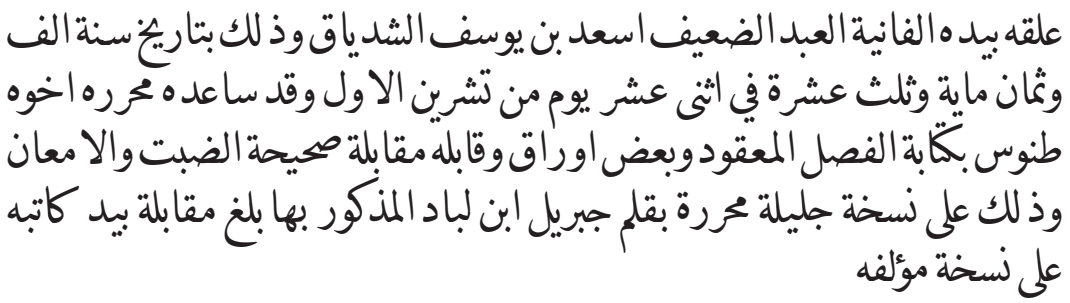

It was copied ('allaqahu) by the perishable hand of the feeble servant As'ad b. Yūsuf al-Shidyāq, in the year 1813, on the twelfth day of October. Its transcriber (muharriruhu), his brother, Tannūs, helped him in the writing of [Farhāā's] al-Fașl al-ma'qūd and some folios, and collated it with sound precision and examination (qäbalahu șahịhat al-dabt wa-l-im'än), according to an important, well-transcribed copy (nuskha jalīla wa-muharrara) by Jibrill ibn Labbād, who is mentioned in it. It was completed by collation (balagha muqābalatan) by its scribe according to a copy by its author. ${ }^{52}$

51 On the afterlives of Farhāat's grammar, see the contribution by Rossella De Luca in this volume. 
These normative scribal conventions-collation, correction, assiduously checking against reliable exemplars-suggest more than a slavish conformity to authority, as the cliché about scribal culture on the eve of modernity would have it. Nor were these scribes indulging in any kind of esotericism or obscurantism. ${ }^{53}$ Instead, such notes are clear statements of the scribe's own authority and agency, through which he plays an active and dynamic role in a text's mediation. ${ }^{54}$ The comparing of Farhạat's text against an "important, well-transcribed copy" further attests to the embeddedness of traditional Islamo-Arabic methods of textual criticism among Christian scribes. While nineteenth-century European philology would privilege the most ancient exemplars in the making of an edition, pre-existing Arabic practices tended to assess the reliability of copies based on the robustness of their transmission. ${ }^{55}$ As also mentioned in the above colophon, As'ad completed his copy of Farhāat's grammatical works in 1813. This would have been some eight years before he entered the employ of the Protestant Syria Mission in $1825 .{ }^{56}$ That manuscripts copied by members of the Shidyāq family made their way into the mission's archives suggests that the American "Biblemen" of the ABCFM were being brought into contact with an active and systematic scribal culture.

Such scribal practices were also brought to bear on the Arabic print culture established by European and American missionary organisations. As Hala Auji has observed, books printed in Beirut by American missionaries in the $1830 \mathrm{~s}$ closely followed modes and conventions common to Arabic manuscripts. Thus, when the American Press was established in 1834, it "found itself at the nexus between age-old scribal traditions and emergent printing traditions." 57 This nod to manuscript-based culture in the Amp's early editions was not only visual. As in Cairo's Būlāq Press (discussed previously), AmP employees trained as manuscript copyists (nussākh) and correctors (mușahhiḥūn) applied their know-how to ensuring the textual quality of printed books. 58

A central figure in the AMP's editorial processes was Nāșîf al-Yāzijī, a Greek Catholic. Like the Shidyāqs, al-Yāzijī hailed from an eminent family of notaries, having himself worked as a private secretary for local families in Mount

53 See the remarks by Elizabeth Eisenstein and Geoffrey Roper discussed in Section 1 of this article.

54 On this function of the scribe in Arabic manuscript production, see Quiring-Zoche, "The Colophon in Arabic Manuscripts," 73-76; Feras Krimsti, "Signatures of Authority: Colophons in Seventeenth-Century Melkite Circles in Aleppo" (forthcoming).

55 Dayeh, "From Tașhịh to Tahquiqq," 269.

56 Makdisi, Artillery of Heaven, 104.

57 Auji, Printing Arabic Modernity, 35.

58 Aujī, Printing Arabic Modernity, 34. 
Lebanon before entering the service of the Aвсғм's Syria Mission. ${ }^{59}$ An active copyist throughout his career, thirteen manuscripts in the NEST collection are known to have been produced by him (excluding drafts and corrections of what would later become known as the Van Dyck Bible). These contained works on subjects as diverse as Arabic grammar, logic, history, music, and even Islamic theology. ${ }^{60} \mathrm{Al}$-Yāzijī was also an author in his own right and was closely involved in the printing of his own works. Among these was his grammar entitled Faṣl al-khițāb fì uṣūl lughat al-a'rāab ("Final Conclusion Concerning the Foundations of the Arabic Language"), first printed by the AMP in 1836 and several times thereafter. His first edition of this work contains several features reminiscent of contemporary manuscript production. These include an ornamental basmala in the form of an Ottoman tughrā and the invocation of Qurānic verses in the colophon, namely qul allāhu ahad from Sūrat al-Ikhlāṣ, presumably to appeal to a wider readership. ${ }^{61}$ In a later edition of the Fașl al-khițāb, prepared by al-Yāzijī himself in 1847 and printed in 1854, one finds further features comparable with those found in manuscripts. To facilitate the comparison, I have placed the printed colophon of al-Yāzijì's 1854 edition alongside a colophon in one of his manuscripts from NEST (see also Fig. 4):

NEST AB 67 (copied 1846-7)

Faṣl al-khițāb fìuṣūl lughat al-i'rāb

(printed 1854)

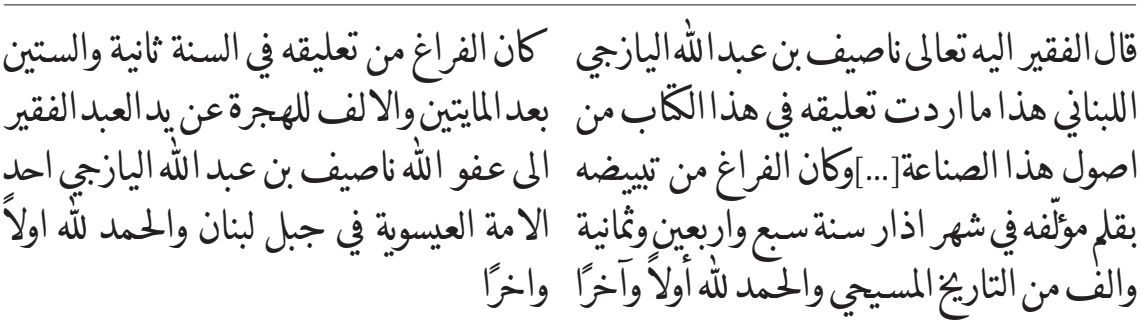

59 Philip Sadgrove, "Al-Yāzid̦jī," in Encyclopedia of Arabic Literature, eds. Julie Scott Meisami and Paul Starkey, 2 vols. (London: Routledge, 1998), 2:813.

6o These are: NEST AB 13; NEST AB 25; NEST AB 36; NEST AB 67; NEST AB 7; NEST AH 2; NEST AH 3 ; NEST AH 4 ; NEST AH 5 ; NEST AH 15; NEST AO 47; NEST AO 54; NEST AP 7. See descriptions in Pollock and Pollock, "Catalogue."

61 For a discussion of the țughrā in the first edition of al-Yāzijī's Faṣl al-khițāb, see Geoffrey Roper, "The Beginnings of Arabic Printing by the ABCFM, 1822-1841," Harvard Library Bulletin 9, no. 1 (1998): 52; Auji, Printing Arabic Modernity, 39-42. On the use of Quranic formulae in the opening praises of early printed Arabic books, see Auji, Printing Arabic Modernity, 123. For al-Yāzijī's colophon in the first edition of his Faṣl al-khițāb, see Nāṣif al-Yāzijī, Kitāb faṣl al-khițāb fì lughat al-i'rāb (Beirut: n.p., 1836), 268. 
(cont.)

NEST AB 67 (copied 1846-7)

Faṣl al-khiṭāb fì uṣūl lughat al-i'rāb

(printed 1854)

Its transcription (talīqihi) was completed in the year 1263 of the Hijra by the servant in need of God's forgiveness, Nāṣîf b. 'Abd Allāh al-Yāzijī, a member of the Christian community (ahad al-umma al-'isawiyya) in Mount Lebanon. Praise be to God, firstly and lastly. ${ }^{62}$

Nāṣịf b. 'Abd Allāh al-Yāzijī al-Lubnānī, the one in need of the Almighty, said: This is what I wished to compose (talíqihi) in this book from the foundations of this craft [...] Its composition (tabyịdihi) was completed by the pen of its author in the month of March 1847 of the Christian calendar. Praise be to God, firstly and lastly. ${ }^{63}$

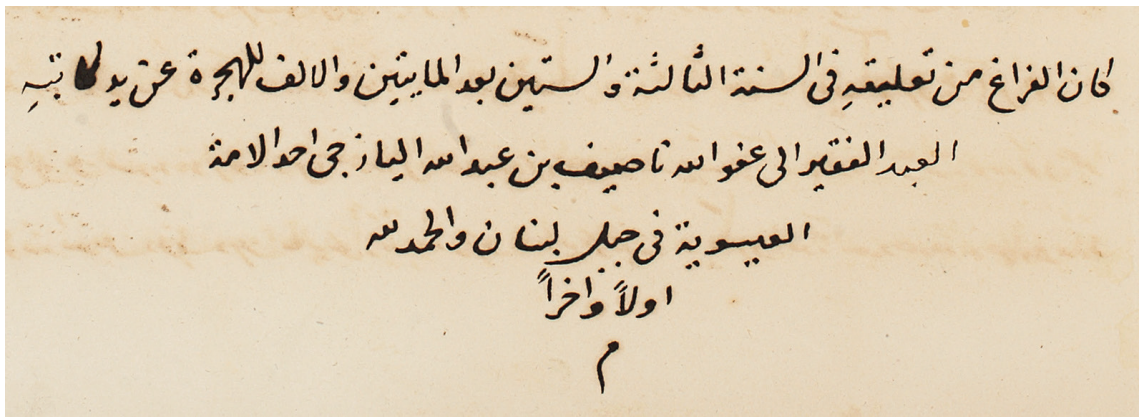

FIGURE 4 NEST AB 67: Colophon by Nāṣīf al-Yāzijī, dated 1263/1846-7

What is striking here is that the terms taclīq (lit. "joining") and tabyīe (lit. "whitening") are usually employed in Arabic manuscript colophons to mean both "composition" and "transcription," along with many others such as kitāba (lit. "writing"), tahrīr (lit. "editing"), and taswid (lit. "blackening"). ${ }^{64}$ Of further note are formulae expressing humility on the part of the scribe (al-faqì ila 'afw allāh and al-faqīr ilä rabbih) being used in reference to a printed work's author. ${ }^{65}$ A more personal flourish is al-Yāzijī's use of the expression "praise be to God,

\footnotetext{
$62 \quad$ NEST AB 67 , fol. 526 r.

63 Nāṣîf al-Yāzij̄ì, Faṣl al-khiṭāb fì uṣūl al-lughat al-írāb (Beirut, 1854), 124.

64 François Déroche, Islamic Codicology: An Introduction to the Study of Manuscripts in Arabic Script, trans. Deke Dusinberre (London: Al-Furqān Islamic Heritage Foundation, 2005), 320; Gacek, Arabic Manuscripts, 282. See also the occurrence of the verb 'allaqa in NEST AB 66, transcribed and translated above.
}

65 Gacek, Arabic Manuscripts, 239. 
firstly and lastly" (al-hamd li-lläh awwalan wa-äkhiran), occurring in both his hand-written and printed colophons. ${ }^{66}$ That al-Yāzijī uses such scribal idioms in a work composed for print is noteworthy. It suggests, on the one hand, that the AMP's inaugural editions were intended to meet the expectations of an audience more accustomed to reading manuscripts. ${ }^{67}$ On the other hand, the persistence of these conventions suggests that al-Yāzijì did not conceive of print as a radical departure from scribal production, especially where he himself was involved in the publication process. Colophons in printed editions were also used by intellectuals in sixteenth- and seventeenth-century England who both authored and oversaw their own publications. Cathy Shrank has observed in these works an "active authorial input" and "rhetorical intimacy" that writers such as William Thomas (d. 1554) invested in the printed form, often by employing humility topoi more commonly found in manuscripts. ${ }^{68}$ Al-Yāzijì's use of comparable methods likewise speaks of an active authorial input into the process of print. The occurrence of these features in printed works should prompt us to think of manuscript culture as an integral feature of the nahda, particularly among its first generation of intellectuals.

\section{Entangled Grammatical Traditions: Arab Christians as Readers and Copyists of Ottoman Grammar}

Having examined the ways in which traditional scribal practices informed the activities of early nahda thinkers, we now turn to a related area of intellectual production: the Arabic language sciences. We have already observed that many of the manuscripts copied by various men of the nahda dealt with grammatical subjects. The intersection between grammatical and scribal labour should not surprise us: "native" specialists were not only valued by foreign missions for their text-criticism but also for their extensive expertise in "Standard Arabic,"

66 For example, NEST AO 54 (on which more below).

67 Auji, Printing Modernity, 38-39; Roger Chartier, "The Printing Revolution: A Reappraisal," in Agent of Change: Print Culture Studies after Elizabeth L. Eisenstein, eds. Sabrina A. Baron et al. (Amherst [MA]: University of Massachusetts Press, 2007), 397-408; idem, "Le manuscrit à lâge de l'imprimé (XVème.-XVIII ème. siècles): lectures et réflexions," La Lettre Clandestine 7 (1998): 178-93; David McKitterick, Print, Manuscript, and the Search for Order, 1450-1830 (Cambridge: Cambridge University Press, 2003), 37, cited in Auji. Printing Modernity, 39 .

68 Cathy Shrank, “These Fewe Scribbled Rules': Representing Scribal Intimacy in Early Modern Print," Huntington Library Quarterly 67, no. 2 (2004): 303f. On the circulation of scribally published works in early modern England, see Harold Love, Scribal Publication in Seventeenth-Century England, Oxford Scholarship Online (Oxford: Clarendon, 1993). 
or al-fușḥā. As early as 1836, Nāșîf al-Yāzijī, a man steeped in scribal culture, was also helping American missionaries to render colloquial Arabic translations of English works into the literary tongue. ${ }^{69}$ Al-Yâzijī continued in this role during his work on the Bible translation with Eli Smith and Butrus al-Bustānī. Initial drafts were produced by al-Bustānī, checked by Smith, and then revised by al-Yāzijī "to eliminate words and idioms inadmissible by classical standards." ${ }^{70}$ Al-Yāzijī was also involved in the Majma al-tahdhìb (Refinement Council, est. 1846), a society of Christian Arab converts to Protestantism wishing to train itinerant preachers. Although al-Yāzijī never left the Greek Catholicism of his birth, his work with the Council helped acquaint its members with the Arabic eloquence needed to promote evangelism. ${ }^{71}$

Interest in maintaining high standards in Arabic is amply reflected in the NEST collection. Of the 283 distinguishable Arabic titles among NEST's manuscripts, 69 belong to the genre of grammar, rhetoric, semantics, prosody, and lexicography. Noteworthy is that many of these grammatical manuscripts belong to an Ottoman commentary tradition that has hitherto been neglected in the context of the nahda. ${ }^{72}$ Even as new modes of intellectual production emerged over the course of the nineteenth century, this Ottoman tradition remained at the forefront of grammatical pedagogy during the nahda, both among Arab intellectuals and American missionaries. As such, manuscripts from the NEST collection that contain such texts present us with further points of continuity with earlier modes of scholarly praxis.

In Section 1, I surveyed past approaches that have assessed pre-nahda intellectual traditions through the rubric of decline. Such narratives were also prominent among many nineteenth-century Arab intellectuals who tended to glorify a classical, Abbasid age while rejecting an immediate Ottoman past. ${ }^{73}$ In his Khuțba fì ādāb al-'arab ("Lecture on the Literature of the Arabs"), delivered in 1859, Buțrus al-Bustānī maintained that Arab learning-including

\footnotetext{
69 Auji, Printing Modernity, 34.

70 Tibawi, American Interests, 123.

71 Anthony Edwards, "Revisiting a Nahḍa Origin Story: Majma' al-Tahdhïb and the Protestant Community in 1840 s Beirut," Bulletin of the School of Oriental and African Studies 82, no. 3 (2019): 427-51. The Council of Refinement prefigured the establishment of the 'Abayh Seminary in 1846 from which NEST traces its origin.

72 A notable and recent exception has been El Shamsy, Rediscovering the Islamic Classics, 54-62.

73 Manfred Sing, "The Decline of Islam and the Rise of Inhitâtạ: The Discrete Charm of Language Games about Decadence in the 19th and 2oth Centuries," in Inhițāt: The Decline Paradigm: Its Influence and Persistence in the Writing of Arab Cultural History, ed. Syrinx von Hees (Würzburg: Ergon, 2017), 11-70.
} 
the linguistic sciences (al-ulüm al-lughawiyya) — had been in a total state of decline since the fourteenth century. ${ }^{74}$ Reflecting favourably on the European and American presence in the Middle East, al-Bustānī expresses the hope that the example set by Catholic and Protestant missionaries might help the Arabs to recapture the achievements of Islamic Spain and Abbasid Baghdad. ${ }^{75}$

However, the manuscripts of the NEST collection tell a very different story. While the achievements of post-Abbasid Arabic scholars are entirely absent from al-Bustānīs survey of Arabic literature, they are found in considerable abundance among the manuscripts acquired by the Syria Mission. Indeed, few of the Arab grammarians and rhetoricians of al-Bustānīs vaunted Abbasid age appear in this repository. Instead, many of the works contained in these manuscripts belong to a later textual tradition characterised by a bipartite or tripartite scheme, consisting of the base text (matn, pl. mutūn); commentary (sharh, pl. shurūh); and marginal gloss or supercommentary (häshiya, pl. hawāshì). Among them in the NEst collection are copies of:

- The Miftāh al-'ulüm ("Key to Sciences"), a manual on rhetoric by Yūsuf b. Abī Bakr al-Sakkākī (d. 1229). This work is often -if not always-accompanied by an abridgment entitled Talkhiș al-miftăh ("Abridgement of the Key") by Jalāl al-Dīn al-Qazwīnī (d. 1338); Qazwīnī's al-Ị̣̇āh fì al-ma'ānì wa-l-bayān ("Explanation of Semantics and Rhetoric"), an expanded version of his Talkhīṣ; a short and long commentary on al-Qazwīnī's abridgement (al-Sharh al-mukhtașar ["The Short Commentary"] and al-Muțawwal ["The Long Commentary"] respectively) by Sa'd al-Dīn al-Taftāzānī (d. 139o); glosses on al-Qazwīnī's al-Muțawwal by al-Sayyid al-Sharīf al-Jurjānī (d. 1413); and a treatise by 'Abd al-Rahīm b. 'Abd al-Raḥmān al-'Abbāsī (d. 1555/6) on literary examples (shawāhid) given in the Talkhiṣ:;7

- The Alfiyya, a famous pedagogical poem on grammar by Ibn Mālik (d. 1274), with commentaries and glosses by Badr al-Dīn Ibn Mālik (d. 1287), Khālid

74 Buțrus al-Bustān̄i, Khuțba fì ādāb al-'arab in A'māl al-Jam'iyya al-Tlmiyya al-Sūriyya, 18681869: majmū'at al-'ulūm, ed. Yūsuf Q. Khūrī (Beirut: Dār al-Ḥamrā', 1990), 114.

75 Al-Bustānī, Khuțba, 112. On al-Bustānī's praise of European cultural successes more generally, particularly in connection with nahda notions of progress (taqaddum) and civilisation (tamaddun), see Stephen Sheehi, "Epistemography of the Modern Arab Subject: Al-Mu'allim Butrus Al-Bustani's Khutbah Fi Adab-Al'Arab," Public 16 (1997): 65-84.

76 NEST AB 3 (1055 AH/1645 AD), with al-Qazwīnīs Talkhiss and Taftāzānīs Mukhtaṣar; NEST AB 11 (1091 AH/1680 AD), with al-Qazwīnīs Talkhiss and gloss by al-Jurjānī; NEST AB 40 (1153 AH/1740 AD), with al-Qazwīnìs Talkhịs and al-Taftāzānī's al-Mukhtașar; NEST AB 48 (1168/1755), with al-Qazwīnī's Talkhịs and al-Abbāsīs treatise; NEST AB $5^{8}$ (ca. 17th-18th century), with al-Qazwīni’s Talkhiș and Ị̇āh with anonymous gloss; NEST AB 59 (793/139o), with al-Qazwīnìs Talkhīs and Ị̇ăḥ; NEST AB 60 (1056/1646), with al-Qazwīnī's Talkhīṣ and al-'Abbāsìs treatise; NEST AB 69 (1107/1696), with al-QQazwīnī's Talkhīṣ and al-Taftāzānī's Muțawwal. 
b. 'Abdallāh al-Azharī (d. 1499), 'Abdallāh b. 'Abd al-Raḥmān b. 'Āqil (fl.ca. 1294-1367), Badral-Dīnal-'Aynī(d.1451), 'Alīb. Muhạmmad al-Ushmūnī (d. 1494/5), and Zakariyā’ b. Muhmmammad al-Anșārī (fl. ca. 1423-1520);77

- The Miṣbāh fi al-naḥw ("The Lamp concerning Grammar") of Nāṣir b. alSayyid al-Muțarrizī (d. 1213), with commentaries and glosses by Tāj al-Dīn al-Isfarāyinī (d. 1285), the aforementioned al-Taftāzānī, and Yáqūb Sayyid 'Alīzādeh (fl. 16th century). ${ }^{78}$

The presence of these works in the library of the Syria Mission is far from incidental, since they were highly popular in Ottoman colleges. ${ }^{79}$ Many of the names associated with this textual tradition flourished between the Mongol, Timurid, and Mamluk eras. Several eastern-Islamic authors such as Isfarāyinī were first brought to Ottoman Arab and Turkish lands in the seventeenth century by Kurdish and Azeri scholars fleeing Safavid incursions into the eastern frontiers of the Ottoman Empire. These late medieval and early modern scholars were regarded in Ottoman medreses as leading authorities on grammar and rhetoric (among other subjects), such that their commentaries became subject to numerous glosses. ${ }^{80}$ These commentators and glossators were also regarded as representatives of the school of tahqiq ("verification") and contributed to the emergence of ādāb al-bahth wa-l-munāzara ("disciplines of investigation and disputation") — a distinct feature of the early modern Ottoman intellectual landscape. ${ }^{81}$ Moreover, the text-centred method of teaching embodied in these commentaries and glosses facilitated the emergence of what Khaled El-Rouayheb has termed "deep reading," the transmission of knowledge

77 NEST AB 39 (1845 AD), with commentary by al-Azharī; NEST AB 41 (1085 AH/1674 AD), with commentary by Ibn Mālik and gloss by al-Anșārī; NEST AB 45 (1128 AH/1715 AD), with commentary by Ibn 'Āqil; N E ST AB 55 (1043 AH/1634 AD), with commentary by al-'Aynī; NEST AB 62 (undated), with commentary by al-Ushmūnī; NEST AB 63 (undated), with commentary by al-Ushmūnī.

78 NEST AB 17 (1062 AH/1652 AD), with commentary by al-Isfarāinī; NEST AB 18 (ca. 18th century), with commentary by al-Taftāzānī and gloss by 'Alīzādah; NEST AB 26 (ca. 17th-18th century AD), with commentary by al-Isfarāinī.

79 On the popularity of commentaries and glosses on al-Sakkākī's Miftāh al-ulūm, Ibn Mālik's Alfiyya, and al-Muțarrizī's Mișbāḥ, see William Smyth, "Controversy in a Tradition of Commentary: The Academic Legacy of Al-Sakkākīs Miftāh al-'Ulūm," Journal of the American Oriental Society 112, no. 4 (1992): 589-97; Rudolf Sellheim, "Al-Muțarrizī," in Encyclopaedia of Islam, New Edition, Volume 7, eds. Clifford E. Bosworth et al. (Leiden: Brill, 1993), 773-74; El-Rouayheb, Islamic Intellectual History, 27, 37, 142; Sidney Glazer, "The Alfiyya of Ibn Malik, its Importance and Place in Arabic Grammatical Science," Moslem World 41 (1941): 274-79.

8o El-Rouayheb, Islamic Intellectual History, 13-59.

81 Khaled El-Rouayheb, "Opening the Gate of Verification: The Forgotten Arab-Islamic Florescence of the 17th Century." International Journal of Middle East Studies 38, no. 2 (2006): 263-81; idem, Islamic Intellectual History, 6o-96. 
centered on the careful perusal (muțālaca) of key texts. ${ }^{82}$ Far from limiting intellectual development, this method of layered and discursive learning served as a vehicle for rigorous enquiry. ${ }^{83}$ Alongside grammar and rhetoric, Aristotelian logic functioned as another means of analysing seminal texts. A key primer to logic was the İsäghüji (Isogoge) of another Mongol-era writer, Athīr al-Dīn al-Abharī (d. 1262 or 1265). ${ }^{84}$ This work drew attention from several generations of commentators and glossators during the post-Mongol, Timurid, Mamluk, and Ottoman eras. Among them were Ḥusām al-Dīn al-Kātī (d. 1359), Shams al-Dīn al-Fanārī (d. 1453), Zakariyyā’ al-Anșārī (d. 1519), and Qūl Aḥmad b. Khidr (d. ca. 1543). ${ }^{85}$ Such texts enjoyed a special esteem among many Ottoman Islamic jurists who regarded logic as not only commendable but also as a religious obligation, particularly for those embarking on the study of law and theology. ${ }^{86}$

This post-classical tradition of logic represents yet another site of encounter between Muslims and Christians in the Ottoman Empire. An adjacent tradition of Arabic logic was derived from early modern Latin models and had percolated into Catholic institutions throughout the Middle East, its chief representatives being Buțrūs al-Tūlāwī (1657/8-1746) and Joseph Assemani (1687-1768). ${ }^{87}$ Yet Christians were also familiar with foundational texts on logic by Muslim writers, not least al-Abharī's İsäghüjī and its commentary tradition, which can be found throughout several ecclesiastical and monastic collections in the Middle East. ${ }^{88}$ Arab Christians not only read this text; they also actively

82 El-Rouayheb, Islamic Intellectual History, 97-128; idem, "The Rise of 'Deep Reading' in Early Modern Ottoman Scholarly Culture," in World Philology, eds. Sheldon Pollock, Benjamin A. Elman, and Ku-ming Kevin Chang (Cambridge [MA]: Harvard University Press, 2015), 201-24.

83 Smyth, "Controversy in Tradition," 596; Ahmed, "Post-Classical Philosophical Commentaries/Glosses."

84 On this work and its contents, see El-Rouayheb, The Development of Arabic Logic, ${ }_{2}^{2}$.

85 El-Rouayheb, The Development of Arabic Logic, 52.

86 While there were dissenting voices, the mainstream of Sunnī legal opinion in the Ottoman Empire tended to look favorably upon the study of logic until the rise of Salafism in the nineteenth and twentieth centuries. See Khaled El-Rouayheb, "Sunni Muslim Scholars on the Status of Logic, 1500-180o," Islamic Law and Society 11, no. 2 (2004): 213-32.

87 See El-Rouayheb, The Development of Arabic Logic, 26o-74; Antoine Moukarzel, "Buțrus al-Tūlāwī et Son 'Traité Sur La Logique," Parole de l'Orient 27 (2002): 263-80.

88 Walbiner, "Monastic Reading," 470-71. See also instances in Maroun Aouad et al., "Catalogue raisonné des manuscrits de philosophie en langue arabe de la Bibliothèque Saint Paul de Harissa (Première partie)," Mélanges de l'Université Saint-Joseph 61 (2008): 190-341. As for other Middle Eastern Christian collections, several other copies can be accessed via the HMML Virtual Reading Room (vhmml.org). These are the following: Melkite Archdiocese, Aleppo: GCAA 78 (1764), with commentary by al-Kātī; GCAA 153 
engaged with its contents. The Greek Catholic typographer, 'Abdallāh Zākhir (1684-1748), studied logic in Aleppo under the Muslim grammarian and logician Sulaymān al-Naḥawī (d. 1728), and wrote his own unfinished commentary on al-Abharì's $\bar{I} s \bar{a} g h \bar{u} j \bar{l}$, later completed by a junior contemporary, Yuwākīm Muțān (d. 1766). ${ }^{89}$ The legacy of Abharì's İsäghüjī is likewise present in the NEST collection, which contains a copy of Fanārì's commentary with glosses by Qūl Aḥmad (NEST AB 21), dated 1078 AH/1667 AD, and another copy of Fanārī's commentary produced by Nāṣif al-Yāzijī (NEST AO 54) between 1840-50, based on an ownership mark by Eli Smith.

It is clear that foreign missionaries such as Smith were encountering a current tradition of logic within learned Ottoman circles. Fanārī's commentary on the İsäghüjī, together with Qūl Aḥmad's glosses, was published as a lithograph in Istanbul in 1861, while an earlier lithograph of Fanārī's commentary, this time containing Qara Khalī Tīrevīs (1711) glosses, was printed in 1873/4. ${ }^{90}$ It was precisely because of the popularity of al-Abharîs $\bar{I} s \bar{g} g h \bar{u} j \bar{\imath}$ and its exegetical layers that it would later be printed. It is also noteworthy that this tradition of logic was in line with pedagogical methods approved by the Muslim 'ulama $\vec{a}^{3}$ of the Ottoman Empire (as mentioned above). The endurance of this tradition suggests that "Islamic" modes of knowledge production were not wholly eclipsed by "secular" models. For not only were manuscripts from this tradition held in ecclesiastical libraries throughout the empire; they were also of interest to Christian intellectuals such as al-Yāzijī and his missionary associates.

(1772), with commentary by al-Kātī; George and Mathilde Salem Foundation, Aleppo (olim Sbath): GAMS $9 \circ 9$ (1161/1748), with commentary by al-Kātī and glosses by Muhyī al-Dīn al-Tālijī (active 1479); Mār Behnām Monastery, Mosul: M BM 446 (ca. 19th-2oth century), with commentary by Sulaymān b. 'Abd al-Raḥmān al-Jarbī (fl. 16th century); MBM 433 (ca. 19th century), with commentary by Nūr 'Alī Shāh (d. 1797/98); Ordre Basilien Alepin, Jounieh: ОВA 684 (1685), with commentary by al-Kātī and glosses by al-Tālijī and Muḥammad b. Muḥammad al-Barda'ī (d. 1520/21); ОвA 682 (1790), with commentary by al-Kātī; OBA 1131 (ca. 17th century), with commentary by al-Fanārī; Syrian Catholic Archdiocese, Baghdad: ASCBN 11 (1841), without commentary; ASCBN 118 (ca. 17th-19th century), with commentary by al-Kātī and al-Fanārī and glosses by Qūl Ahmad.

89 Zākhir's commentary is entitled Sharh al-ușūl al-manțiqiyya 'alā al-risāla al-abhariyya ("Commentary of the Foundations of Logic according to al-Abharīs Treatise"); see Georg Graf, Geschichte der christlichen arabischen Literatur, 5 vols. (Città del Vaticano: Biblioteca apostolica vaticana, 1944), 3:199-200. Yuwākīm Muțrān wrote his own treatise on logic but did so based mainly on European models; see El-Rouayheb, The Development of Arabic Logic, 275-83.

90 Shams al-Dīn al-Fanārī, Sharh İsāghūjī (Istanbul: al-Mațba‘a al-Ḥarbiyya, 1278/1861), printed with gloss by Qūl Aḥmad; Qara Khalìl Tīrevī, Ḥāshiyat Qara Khalīl 'alā al-Fanārī (Istanbul: Yahyā Efendī, 1289/1873-1874). 
We have so far seen how a late medieval and early modern tradition of Ottoman grammar, rhetoric, and logic had percolated into learned Christian Arab circles by the eighteenth and nineteenth centuries. We should also note that such texts were actively sought by intellectuals whom the historiography of the nahda remembers as key figures in the emergence of Arab modernity. As we learn from the statutes of the ssas, a major acquisition of some 756 Arabic and Turkish manuscripts and printed books was conducted by Ni'mat Allāh al-Thābit with the help of the British diplomat Charles Henry Churchill (18071869). As mentioned in the introduction to this study, these manuscripts would later pass into the care of Eli Smith. Of interest here is that many of these items seem to have been acquired from Muslim owners, since a large number are listed as books on Islamic jurisprudence, Sufism, and hadith.${ }^{91}$ After Islamic jurisprudence, however, the most represented genres are grammar (73 manuscripts), logic (31 manuscripts), and rhetoric (12 manuscripts). Although the statutes of the ssas do not list these manuscripts by name, it is likely that they contained several of the post-classical works discussed previously in this section. Moreover, after the ssas library passed to the newly founded Syrian Protestant College, they were immediately put to use in the curriculum. For example, among the manuscripts studied in the sPc's philosophy and sciences elective was a copy of the Sharh al-hidāya of Shams al-Dīn b. Mubārak-Shāh (d. ca. 1334), a commentary on al-Abhari’s Hidāyat al-hikma. ${ }^{92}$ It is likely that such post-classical works held at NEST were similarly acquired for their pedagogical value.

91 Statute 15 of the Society report categorises the books as follows (anonymous, "Gesellschaft," 378): 129 books on jurisprudence (al-fiqh); 73 on grammar (al-șarf wa-l-naḩw); 64 misc. (mukhtalifät shatta); 57 on grammatical analysis and exegesis of the Qurān (i'rāb al-qur'ān wa-tafsìr); 31 on logic (manțiq); 27 on Sufism and composition (al-ilm al-ḩaqīqa wa-l-ädāb wa-shay' min al-inshä); 23 hadìth; 24 on medicine (țibb); 20 on poetry (shi'r); 12 on rhetoric (bayān); 11 in Turkish (bi-l-lugha al-turkiyya); 9 on mathematics (ḥisāb wahandasa); 8 on astronomy ('ilm al-nujūm).

92 Chebaro and El Mikati El Kaissi, "Manuscript Ownership," 269. The manuscript in AUB's permanent collection is Jafet Library, MS16o:I942sA, copied in Anatolia in the fifteenth century, bearing seal impressions of the sultan Beyazīd II (r. 1481-1512). For a full description, see Yūsuf Q. Khūrī, al-Makhțūțāt al-'arabiyya al-mawjūda fì Maktabat al-Jāmi'a al-Amìrikiyya fì Bayrūt (Beirut: Markaz al-Dirāsāt al-'Arabiyya wa-Dirāsāt al-Sharq al-Awsaț, al-Jāmi‘a al-Amīrikiyya, 1985), 15 (nº 38). 


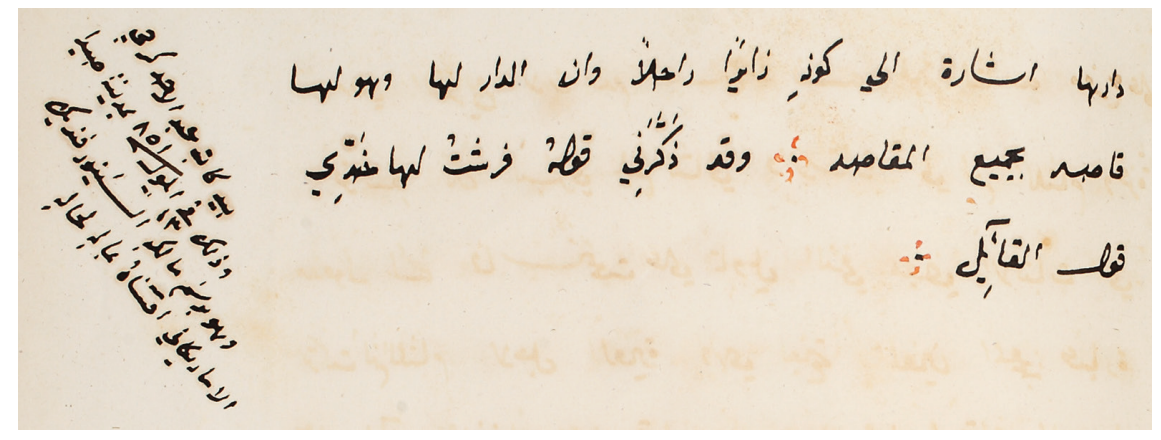

FIGURE 5 NEST AB 32: Colophon mentioning commission by Cornelius van Dyck, dated 1851

In addition to being of interest to the Christian Arab intellectuals mentioned thus far, such works also came to the attention of American Arabists at the Syria Mission. The colophon of one NEST manuscript of the Dīwān of Ibn al-Fārid (d. 1234), which contains the commentary by the Damascene prosodist and grammarian Hasan al-Būrīnī (d. 1615), informs us that it was commissioned by Cornelius van Dyck in Sidon in 1851 (see Fig. 5) $\cdot{ }^{93}$

We should note here that Van Dyck was accessing classical Arabic poetry through an early modern tradition of Arabic pedagogy. For al-Būrīnī exemplifies many of the intellectual currents discussed so far, having studied the semantic works of al-Taftāzānī and taught the commentaries on al-Sakkākī's Miftāh al-'ulūm and al-Kātī's commentary on al-Abharī's Isāghūjī.94 Such works also informed the linguistic activities of the Syria Mission more generally. Although Eli Smith and Cornelius Van Dyck are often credited with the famous Arabic Bible translation carried out between 1848 and 1865, the project was in fact a collaborative effort between Smith, Van Dyck, al-Yāzijī, al-Bustānī, and even Muslim intellectuals such as Yūsuf al-Asīr (1815-1889). ${ }^{95}$ Yet in addition to employing local knowhow, Smith and Eli were also indebted to an early modern current of language science that was still very much alive

93 NEST AB 32, p. 1919: bi-yad kātibihi 'Abd al-Ahad Karjī (?) wa-dhālika fì Aylül sanat 1851 bi-madīnat Șaydā wa-huwa bi-rasm mālikihi al-sīnūr Fandayk al-amārkānì iqtināhu bi-mālihi li-ḥālihi.

94 El-Rouayheb, "Opening the Gate of Verification," 265.

95 Tibawi, American Interests, 123, 139; Sara Binay, "Revision of the Manuscripts of the 'So-Called Smith-Van Dyck Bible' Some Remarks on the Making of This Bible Translation," in Translating the Bible into Arabic: Historical, Text Critical and Literary Aspects, eds. Sara Binay and Stefan Leder (Beirut: Orient-Institut, 2012), 76-84; Grafton, The Contested Origins, 227-39. 
in the Ottoman Empire by the mid-nineteenth century. In his survey of lexicographical and grammatical sources employed in the translation, Smith recalls a number of "helps to a full understanding and proper use of the Arabic language" - many of which now reside in the NEST collection. ${ }^{96}$ These include a number of post-classical sources and their commentaries, some of which should now be familiar to us: ${ }^{97}$

- Ibn Mālik's Alfyyya, with the commentary by 'Alī b. Muḥammad al-Ushmūnī (d. 1494/5);98

- Ibn Mālik's Tashïl al-fawā̉id wa-takmīl al-maqāsid (an abridgement of the now lost al-Fawāid fi al-naḩw, "The Utilities concerning Grammar"), with commentary by Muhammad b. Abī Bakr al-Damāmīnī (d. 1424);99

- Al-Taftāzānīs longer (Muțawwal) and shorter (Mukhtașar) commentaries on Qazwīnī's abridgement of al-Sakkākī's Miftāh al-'ulūm. ${ }^{100}$

Thus, despite al-Bustānìs protestations that the light of the Arabic language sciences had long grown dim, it was in fact a thoroughly post-Abbasid intellectual tradition that informed the translation activities of his colleagues in the Syria Mission. While modern historians once maintained that Ottoman scholarship was needlessly complicated by a profusion of commentaries, it was in fact this very commentary culture that helped produce an up-to-date version of the Bible. For many, this Bible version served as a hallmark of Arab modernity as well as Arab Protestant identity. ${ }^{101}$ Prior to the emergence of this new translation, Protestant missionaries in Syria relied on an edition published by the Propaganda Fide in $1671 .^{102}$ The Arabic of this version was intentionally written in what some modern scholars have called "Middle Arabic."103 This mix

96 Van Dyck's survey is recorded in Henry Harris Jessup, Fifty-Three Years in Syria, 2 vols. (New York: Fleming H. Revell, 1910), 1:71-73.

97 Jessu, Fifty Years in Syria, $72-73$.

98 NEST AB 62 (undated).

99 NEST AB 5 O (undated).

100 NEST AB 3 (1055 AH/1645 AD); NEST AB 11 (1091 AH/1680 CE); NEST AB 18 (undated); NEST AB 40 (1153 AH/1740 CE); NEST AB 48 (1168 AH/1755 CE); NEST AB 58 (ca. 17th-18th century); NEST AB 59 (793 AH/139o CE); NEST AB 6o (1056 AH/1646 CE); NEST AB 69 (1107 AH/1696 CE).

101 Grafton, The Contested Origins.

102 On this edition, see John A. Thompson, "The Origin and Nature of the Chief Printed Arabic Bibles, Part II," The Bible Translator 6, no. 2 (1955): 51-55.

103 On so-called Middle Arabic as a socio-linguistic phenomenon, see Joshua Blau, $A$ Grammar of Christian Arabic, Based Mainly on South-Palestinian Texts from the First Millennium (Louvain: Secrétariat du CorpusSCO, 1966); idem, "A Melkite Arabic Literary Lingua Franca from the Second Half of the First Millennium," Bulletin of the School of Oriental and African Studies 57, no. 1 (1994): 14-16; idem, "Are Judaeo-Arabic and Christian Arabic Misnomers Indeed?," Jerusalem Studies in Arabic and Islam 24 (2000): 49-57. For a 
of spoken and formal registers was common throughout Arabic Bible translations until the nineteenth century. ${ }^{104}$ Finding the 1671 Roman edition "in bad taste, or absolutely unintelligible," Eli Smith wished to see the Bible rendered into a language that conformed to the Arabic of the Qurān and the literary standards of educated Muslims more generally. ${ }^{105}$ To do so, it was necessary to make use of a grammatical tradition that was common across educated Ottoman circles, Muslim and Christian alike. The Arab intellectuals of the nahda and their American "Biblemen" colleagues were certainly not the first to do so. As Hilary Kilpatrick has observed, Jirmānūs Farḥāt was among the first Christian Arab intellectuals of the modern period to explicitly work within the Islamic grammatical tradition. ${ }^{106}$ For Protestant Arabists a century later, this grammatical tradition had become all but impossible to ignore.

\section{Conclusions}

Based on the foregoing analysis, I hope to have shown that the material from the NEST collection rather complicates the idea of the nahda as a seismic shift from earlier forms of knowledge production. One important aspect of continuity was the copying and circulation of manuscripts. While it is impossible to deny the impact of print media on the literary output of this period, nahda intellectuals continued to value scribal culture. Far from viewing manuscripts as incommensurable with modern publishing, Arab literati were keen to bring scribal practices with them into the age of print, rather than transition from them. Authors such as Fāris al-Shidyāq, who were entirely at home in the world

status questionis of "Christian Middle Arabic" in sociolinguistics, see Jacques Grand'Henry, "Christian Middle Arabic," in Encyclopedia of Arabic Language and Linguistics, eds. Cornelis H.M. Versteegh and Mushira Eid, 5 vols. (Leiden: Brill, 2006), 1:383-87.

104 The author of the introduction to the 1671 Rome version tells us that a simple style was deliberately employed in the translation because "the Holy Spirit did not wish to make free with the Divine Word (ittisā' al-kalima al-ilāhiyya) by [imposing] narrow limits stipulated by the rules of grammar. Thus, the heavenly mysteries preceded us without fluency and elegance (bi-ghayr fașāha wa-balägha), in simple and uncomplicated words, so that man might dedicate his faculty and artifice to the working of his wondrous salvation." Introduction, Biblia Sacra Arabica: sacrae congregationis de propaganda fide iussu edita ad usum Ecclesiarum Orientalium, additis é regione bibliis latinis vulgatis (Rome: Typis eiusdem Sacrae Congregat. de Propaganda Fide, 1671), 1:[5]. On this passage, see also Issa, "Rakākah and the Petit Quarrel," 152.

105 Grafton, The Contested Origins, 125.

106 Hilary Kilpatrick, "From Literatur to Adab: The Literary Renaissance in Aleppo around 170o," Journal of Eastern Christian Studies 58, no. 3-4 (2006): 208. For Farḥāt's sources, which include Ibn Mālik's Alfiyya, see Patel, The Arab nahḍah, 51. 
of print, also saw great value in the scribal art-not only for its aesthetic value but also for its ability to produce reliable texts. While there were no doubt poor scribes (as indeed there were poor printers), the scribal tradition inherited by Fāris al-Shidyāq was one that valued accuracy and meticulousness. We have encountered such concerns in various NEST manuscripts produced by his father, Yūsuf, and his brothers, As'ad and Țannūs. It comes as little surprise, then, that Christian Arab copyists for the Syria Mission of the АвсFм later became correctors and printers, not only of their own works but also of their own Arabic-language heritage.

A further point of continuity was the reading and teaching of the Arabic language through a multi-layered textual tradition of commentaries and glosses. Long thought to be signs of post-classical decline, such texts were in fact highly popular throughout Ottoman schools, and so their presence in Christian collections is hardly surprising. While contacts with Rome and Western missionaries would certainly have an impact on the intellectual landscape, Ottoman trends in grammar, rhetoric, semantics, and logic were equally prevalent among the Empire's Arab Christians. Like their Muslim neighbours, these intellectuals drew on such seminal texts as al-Abharì's Issāghüjī and al-Sakkākī's Miftāh al-ulüm, together with commentaries and glosses on these works. While such names as al-Taftāzānī and Fanārī may not loom large in the Arab nationalist imaginary, they were nevertheless invaluable authorities on grammar and logic whom scholars could scarcely afford to ignore. Such was the case in the Protestant missionary milieu of modern-day Lebanon, where the likes of Eli Smith and Cornelius van Dyck were confronted by a living tradition of Ottoman commentary culture. As such, the manuscripts of the NEST collection were not simply objects of antiquarian interest to those who acquired them. Rather, they contained texts that were of immediate interest and use to the Syria Mission, the SPC, and learned societies like the ssas. For the historian, therefore, the NEST collection serves as a reminder of the nahda's early modern beginnings and a bridge to its immediate Ottoman past.

\section{Acknowledgments}

I should like to thank Hala Auji and Feras Krimsti for their invaluable comments on earlier drafts of this article. I am also grateful to Anthony Edwards for clarifications about the history of various Middle Eastern libraries. Further thanks are owed to the Hill Museum and Manuscript Library for kindly allowing me to reproduce images from the NEST collection. All remaining errors are my own. 


\section{Manuscripts}

Cambridge, University Library, Or. 2215.

NEST AB 1, 3, 5, 7, 11, 12, 13, 17, 18, 21, 25, 26, 32, 39, 40, 41, 45, 48, 50, 55, 58, 59, 6o, 62, 63, $66,67,69$.

NEST AH, 2, 3, 4, 5, 15 .

NEST AO 47, 54 .

NEST AP 7 .

\section{Bibliography}

Ahmed, Asad Q. "Post-Classical Philosophical Commentaries/Glosses: Innovation in the Margins." Oriens 41 (2013): 317-48.

Anonymous. "Gesellschaft der Künste und Wissenschaften in Beirut." Zeitschrift der Deutschen Morgenländischen Gesellschaft 2 (1848): 378-88.

Aouad, Maroun, Philippe Roisse, Emma Gannagé, and Hamidé Fadlallah. "Catalogue raisonné des manuscrits de philosophie en langue arabe de la Bibliothèque Saint Paul de Harissa (Première partie)." Mélanges de l'Université Saint-Joseph 61 (2008): 190-341.

Arberry, Arthur J. "Fresh Light on Ahmad Faris al-Shidyaq." Islamic Culture 26, no. 1 (1952): 156-64.

Auji, Hala. "Printed Images in Flux: Examining Scientific Engravings in NineteenthCentury Arabic Periodicals." In Visuelles Design:Die Journalseite als Gestaltete Fläche / Visual Design The Periodical Page as a Designed Surface, edited by Andreas Beck, Nicola Kaminski, Volker Mergenthaler, and Jens Ruchatz, 199-236. Hannover: Wehrhahn Verlag, 2019.

Auji, Hala. Printing Arab Modernity: Book Culture and the American Press in NineteenthCentury Beirut. Leiden: Brill, 2016.

Bauer, Thomas. "In Search of 'Post-Classical Literature': A Review Article." Mamluk Studies Review 11, no. 1 (2007): 137-67.

Binay, Sara. "Revision of the Manuscripts of the 'so-Called Smith-Van Dyck Bible': Some Remarks on the Making of this Bible Translation." In Translating the Bible into Arabic: Historical, Text Critical and Literary Aspects, edited by Sara Binay and Stefan Leder, 76-84. Beirut: Orient-Institut, 2012.

Blau, Joshua. A Grammar of Christian Arabic, Based Mainly on South-Palestinian Texts from the First Millennium. Louvain: Secrétariat du CorpusSCO, 1966.

Blau, Joshua. "A Melkite Arabic Literary Lingua Franca from the Second Half of the First Millennium." Bulletin of the School of Oriental and African Studies 57, no. 1 (1994): 14-16. 
Blau, Joshua. "Are Judaeo-Arabic and Christian Arabic Misnomers Indeed?" Jerusalem Studies in Arabic and Islam 24 (2000): 49-57.

Bou Ali, Nadia. "Collecting the Nation: Lexicography and National Pedagogy in al-nahda al-'arabiyya." In Archives, Museums and Collecting Practices in the Modern Arab World, edited by Sonja Mejcher-Atassi and John Pedro Schwartz, 34-56. London: Routledge, 2012.

al-Bustānī, Buțrus. "Khuṭba fī ādāb al-'arab.” In A'māl al-Jam‘iyya al- Tlmiyya al-Sūriyya, 1868-1869: majmū'at al-'ulūm, edited by Yūsuf Q. Khūrī, 101-18. Beirut: Dār al-Hamrā', 1990.

Chartier, Roger. "Le manuscrit à l'âge de l'imprimé (XVème.-XVIII ème. siècles): lectures et réflexions." La Lettre Clandestine 7 (1998): 178-93.

Chartier, Roger. "The Printing Revolution: A Reappraisal." In Agent of Change: Print Culture Studies after Elizabeth L. Eisenstein, edited by Sabrina A. Baron, Eric N. Lindquist, and Eleanor F. Shevlin, 397-408. Amherst [MA]: University of Massachusetts Press, 2007.

Chebaro, Kaoukab, and Samar El Mikati El Kaissi. "Manuscript Ownership and Readership at the American University of Beirut at the Turn of the Twentieth Century." In Manuscripts, Politics and Oriental Studies: Life and Collections of Johann Gottfried Wetzstein (1815-1905) in Context, edited by Boris Liebrenz and Christoph Rauch, 248-88. Leiden: Brill, 2019.

Dayeh, Islam. "From Tashịh to Taḥqìq: Toward a History of the Arabic Critical Edition," Philological Encounters 4 (2019): 245-299.

Déroche, François. Islamic Codicology: An Introduction to the Study of Manuscripts in Arabic Script. Translated by Deke Dusinberre. London: Al-Furqān Islamic Heritage Foundation, 2005.

Edwards, Anthony. "Revisiting a Nahḍa Origin Story: Majma' al-Tahdhïb and the Protestant Community in 1840 os Beirut." Bulletin of the School of Oriental and African Studies 82, no. 3 (2019): 427-51.

Eisenstein, Elizabeth L. The Printing Press as an Agent of Change: Communications and Cultural Transformations in Early Modern Europe, 2 vols. Cambridge: Cambridge University Press, 1980.

El-Rouayheb, Khaled. Islamic Intellectual History in the Seventeenth Century: Scholarly Currents in the Ottoman Empire and the Maghreb. Cambridge: Cambridge University Press, 2015.

El-Rouayheb, Khaled. "Opening the Gate of Verification: The Forgotten Arab-Islamic Florescence of the 17th Century." International Journal of Middle East Studies 38, no. 2 (2006): 263-81.

El-Rouayheb, Khaled. "Rethinking the Canons of Islamic Intellectual History." In Studying the Near and Middle East at the Institute for Advanced Study, Princeton, 1935-2018, edited by Sabine Schmidtke, 154-63. Piscataway [NJ]: Gorgias Press, 2018. 
El-Rouayheb, Khaled. "Sunni Muslim Scholars on the Status of Logic, 1500-180o." Islamic Law and Society 11, no. 2 (2004): 213-32.

El-Rouayheb, Khaled. The Development of Arabic Logic (1200-1800). Basel: Schwabe Verlag, 2019.

El-Rouayheb, Khaled. "The Rise of 'Deep Reading' in Early Modern Ottoman Scholarly Culture." In World Philology, edited by Sheldon Pollock, Benjamin A. Elman, and Ku-ming Kevin Chang, 201-24. Cambridge [MA]: Harvard University Press, 2015.

Elshakry, Marwa. "The Gospel of Science and American Evangelism in Late Ottoman Beirut." Past and Present 196, no. 1 (2007): 173-214.

El Shamsy, Ahmed. "Islamic Book Culture through the Lens of Two Private Libraries, 1850-1940." Intellectual History of the Islamicate World 4, no. 1-2 (2016): 61-81.

El Shamsy, Ahmed. Rediscovering the Islamic Classics: How Editors and Print Culture Transformed an Intellectual Tradition. Princeton: Princeton University Press, 2020.

al-Fanārī, Shams al-Dīn. Sharh İsāghūjī. Istanbul: al-Mațba'a al-Harbiyya, 1278/1861.

Findley, Carter Vaughn. "Knowledge and Education in the Modern Middle East: A Comparative View." In The Modern Economic and Social History of the Middle East in Its World Context, edited by Georges Sabagh, 130-54. Cambridge: Cambridge University Press, 1989.

Gacek, Adam. Arabic Manuscripts: A Vademecum for Readers. Leiden: Brill, 2009.

Glazer, Sidney. "The Alfiyya of Ibn Malik, its Importance and Place in Arabic Grammatical Science." Moslem World 41 (1941): 274-79.

Graf, Georg. Geschichte der christlichen arabischen Literatur. 5 vols. Città del Vaticano: Biblioteca apostolica vaticana, 1944.

Grafton, Anthony. Inky Fingers: The Making of Books in Early Modern Europe. Cambridge [MA]: Belknap, 2020.

Grafton, David D. "A Critical Investigation into the Manuscripts of the 'So-Called' Van Dyck Bible." Cairo Journal of Theology 2 (2015): 56-64.

Grafton, David D. The Contested Origins of the 1865 Arabic Bible. Leiden: Brill, 2016.

Grand'Henry, Jacques. "Christian Middle Arabic," in Encyclopedia of Arabic Language and Linguistics, edited by Cornelis H.M. Versteegh and Mushira Eid, 5 vols., 1:383-87. Leiden: Brill, 2006.

Hill, Peter. Utopia and Civilisation in the Arab Nahda. Cambridge: Cambridge University Press, $202 \mathrm{O}$.

Hourani, Albert. Arabic Thought in the Liberal Age, 1798-1939. London: Oxford University Press, 1962.

Introduction. Biblia Sacra Arabica: sacrae congregationis de propaganda fide iussu edita ad usum Ecclesiarum Orientalium, additis é regione bibliis latinis vulgatis. Rome: Typis eiusdem Sacrae Congregat. de Propaganda Fide, 1671.

Issa, Rana. "Rakākah and the Petit Quarrel of 1871: Christian Authors and the Competition over Arabic." In Language, Politics and Society in the Middle East: Essays in 
Honour of Yasir Suleiman, edited by Abeer Al-Najjar and Yonatan Mendel, 148-64. Edinburgh: Edinburgh University Press, 2018.

Jessup, Henry Harris. Fifty-Three Years in Syria. 2 vols. New York: Fleming H. Revell, 1910. Jumayyil, Nāșir. Les échanges culturels entre les Maronites et l'Europe: du Collège maronite de Rome (1584) au Collège de 'Ayn-Warqa (1789). 2 vols. Beirut: n.p., 1984.

Keegan, Matthew L. "Commentators, Collators, and Copyists: Interpreting Manuscript Variation in the Exordium of al-Ḥarīrīs Maqāmāt." In Arabic Humanities, Islamic Thought, edited by Joseph E. Lowry and Shawkat Toorawa, 295-316. Leiden: Brill, 2017.

Khalaf Allah, Muḥammad Aḥmad. Aḥmad Fāris al-Shidyāq wa-ārāunhu al-lughawìya wa-l-adabiyya. Cairo: Jāmi'at al-Duwal al-'Arabiyya. Ma'had al-Dirāsāt al-'Arabiyya al-Lughawiyya, 1955 .

Khalaf, Ghassan, and Stefan Leder. "Tarjamat al-kitāb al-muqaddas ilā al-'arabiyya wa-l-mu'aththirāt." In Translating the Bible into Arabic: Historical, Text-Critical, and Literary Aspects, 7-24. Beirut: Ergon Verlag, 2012.

Khūrī, Yūsuf Q. Al-Makhțūțāt al-'arabiyya al-mawjūda fì Maktabat al-Jāmi'a al-Amìrikiyya fì Bayrūt: dalīl murattab hasab nizām Diyuwīal-'ushrì li-taṣnīf al-kutub wa-tansīqihā ma'a malāhiq wa-kashshāfāt li-l-'anāwìn wa-l-mu'allifinn. Beirut: Markaz al-Dirāsāt al-'Arabiyya wa-Dirāsāt al-Sharq al-Awsaț, al-Jāmi‘a al-Amīrikiyya, 1985.

Kilpatrick, Hilary. "From Literatur to Adab: The Literary Renaissance in Aleppo around 170o." Journal of Eastern Christian Studies 58, no. 3-4 (2006): 196-220.

Krek, Miroslav. "The Enigma of the First Arabic Book Printed from Movable Type." Journal of Near Eastern Studies 38, no. 3 (1979): 203-12.

Krimsti, Feras. "Signatures of Authority: Colophons in Seventeenth-Century Melkite Circles in Aleppo" (forthcoming).

Love, Harold. Scribal Publication in Seventeenth-Century England. Oxford: Clarendon, 1993.

Macdonald, John. Catalogue of Oriental Manuscripts: III. Arabic-150. Leeds: The University of Leeds, Department of Semitic Languages \& Literatures, 1959.

Makdisi, Ussama Samir. Artillery of Heaven: American Missionaries and the Failed Conversion of the Middle East. Ithaca: Cornell University Press, 2008.

McKitterick, David. Print, Manuscript, and the Search for Order, 1450-1830. Cambridge: University Press, 2003.

Moukarzel, Antoine. "Buțrus Al-Tūlāwī et son 'Traité sur la Logique." Parole de l'Orient 27 (2002): 263-8o.

Patel, Abdulrazzak. The Arab Nahdah: The Making of the Intellectual and Humanist Movement. Edinburgh: Edinburgh University Press, 2013.

Pollock, James W., and Rachel Pollock. "Catalogue of Manuscripts of the Library of the Near Eastern School of Theology." The Near East School of Theology Theological Review 4, no. 1-2 (1981): 1-121. 
Quiring-Zoche, Rosemarie. "How Buhārîs Șaḥịh was Edited in the Middle Ages: 'Alī al-Yūnīnī and his Rumūz." Bulletin d'études orientales 50 (1998): 191-222.

Quiring-Zoche, Rosemarie. "The Colophon in Arabic Manuscripts: A Phenomenon without a Name." Journal of Islamic Manuscripts 4, no. 1 (2013): 49-81.

Rastegar, Kamran. Literary Modernity between the Middle East and Europe: Textual Transactions in Nineteenth-Century Arabic, English, and Persian Literatures. London: Routledge, 2007.

Roper, Geoffrey. "Aḥmad Fāris al-Shidyāq and the Libraries of Europe and the Ottoman Empire." Libraries \& Culture 33, no. 3 (1998): 233-48.

Roper, Geoffrey. "Arabic Printing in Malta 1825-1845: Its History and its Place in the Development of Print Culture in the Arab Middle East." PhD diss., University of Durham, 1988.

Roper, Geoffrey. "Fāris al-Shidyāq and the Transition from Scribal to Print Culture in the Middle East." In The Book in the Islamic World: The Written Word and Communication in the Middle East, edited by George N. Atiyeh, 209-31. New York: SUnY Press, 1995.

Roper, Geoffrey. "The Beginnings of Arabic Printing by the ABCFM, 1822-1841." Harvard Library Bulletin 9, no. 1 (1998): 50-68.

Roper, Geoffrey, and Dagmar Glass. "The Printing of Arabic Books in the Arab World." In Middle Eastern Languages and the Print Revolution: A Cross-Cultural Encounter, edited by Eva Hanebutt-Benz, Geoffrey Roper, and Dagmar Glass, 179-8o. Mainz: Gutenberg-Museum, 2002.

Rouse, Mary A., and Richard H. Rouse. "La naissance des index." In Histoire de l'édition française vol. 1: Le livre conquérant: du Moyen âge au milieu du XVII ${ }^{e}$ siècle, edited by Henri-Jean Martin and Roger Chartier, 77-85. Paris: Promodis, 199 o.

Sabra, George F. Truth and Service: A History of the Near East School of Theology. Beirut: Librairie Antoine, 2009.

Sadgrove, Philip. "Al-Yāzid̄jī." In Encyclopedia of Arabic Literature, vol. 2, edited by Julie Scott Meisami and Paul Starkey, 812-13. London: Routledge, 1998.

Sajdi, Dana. "Decline, its Discontents and Ottoman Cultural History: By Way of Introduction." In Ottoman Tulips, Ottoman Coffee: Leisure and Lifestyle in the Eighteenth Century, edited by Dana Sajdi, 1-40. London: I.B. Tauris, 2007.

Salibi, Kamal. Maronite Historians of Mediceval Lebanon. Beirut: American University of Beirut, 1959 .

Salisbury, Edward E. "II. Syrian Society of Arts and Sciences." Journal of the American Oriental Society 3 (1853): 477-86.

Sellheim, Rudolf. “Al-Muțarrizī.” In Encyclopaedia of Islam, New Edition, Volume 7. Edited by Clifford E. Bosworth, Emeri van Donzel, Wolfhart Heinrichs, and Charles Pellat, 773-74. Leiden: Brill, 1993.

Sheehi, Stephen. "Epistemography of the Modern Arab Subject: al-Mu'allim Butrus al-Bustani's Khutbah Fi Adab-Al'Arab." Public 16 (1997): 65-84. 
Sheehi, Stephen. "Towards a Critical Theory of al-Nahdah: Epistemology, Ideology and Capital." Journal of Arabic Literature 43, no. 2-3 (2012): 269-98.

al-Shidyāq, Aḥmad Fāris. Leg over Leg. Or the Turtle in the Tree: Concerning the Färiyāq, What Manner of Creature Might He Be. Edited by Humphrey Davies and Michael Cooperson. 2 vols. New York: New York University Press, 2013.

al-Shidyāq, Ṭannūs. Kitāb akhbār al-a'yān fì jabal Lubnān. Edited by Fu’ād E. Bustānī. 2 vols. Beirut: Publications de l'Université Libanaise, 1970.

Shrank, Cathy. "These Fewe Scribbled Rules': Representing Scribal Intimacy in Early Modern Print." Huntington Library Quarterly 67, no. 2 (2004): 295-314.

Sing, Manfred. "The Decline of Islam and the Rise of Inhițāt: The Discrete Charm of Language Games about Decadence in the 19th and 2oth Centuries." In Inhitât: The Decline Paradigm: Its Influence and Persistence in the Writing of Arab Cultural History, edited by Syrinx von Hees, 11-70. Würzburg: Ergon, 2017.

Smyth, William. "Controversy in a Tradition of Commentary: The Academic Legacy of al-Sakkākī's Miftāh al- 'Ulüm." Journal of the American Oriental Society 112, no. 4 (1992): 589-97.

Starkey, Paul. "Al-Nahḍa." In Encylopedia of Arabic Literature, vol. 1, edited by Julie Scott Meisami and Paul Starkey, 573-74. London: Routledge, 1998.

Suleiman, Yasir. The Arabic Language and National Identity: A Study in Ideology. Edinburgh: University Press, 2003.

al-Ṣulḥ, 'Imād. Aḥmad Fāris: āthāruhu wa-'aṣruhu. 2nd ed. Beirut: Sharikat al-Maṭbū'āt li-l-Tawzī‘ wa-l-Nashr, 1987.

Tadrus, Fawzi M. Printing in the Arab World with Emphasis on the Būlāq Press in Egypt. Doha: Faculty of Humanities and Social Sciences, University of Qatar, 1982.

Thompson, John A. "The Origin and Nature of the Chief Printed Arabic Bibles, Part II." The Bible Translator 6, no. 2 (1955): 51-55.

Tibawi, Abdul Latif. American Interests in Syria, 1800-1901: A Study of Educational, Literary and Religious Work. Oxford: Clarendon Press, 1966.

Tīrevī, Qara Khalīl. Hạshiyat Qara Khalīl 'alā al-Fanārī. Istanbul: Yahyaā Efendī, 1289/1873-1874.

Walbiner, Carsten-Michael. "Ktōbō d-mazmūrē d-Dawīd malkō wa-nbīyō." In The Beginnings of Printing in the Near and Middle East: Jews, Christians and Muslims. Edited by Klaus Kreiser, 22. Wiesbaden: Harrassowitz, 2001.

Walbiner, Carsten-Michael. "Monastic Reading and Learning in Eighteenth-Century Bilād al-Šām: Some Evidence from the Monastery of al-Šuwayr (Mount Lebanon)." Arabica 51, no. 4 (2004): 462-77.

Watson, William J. “İbrāhīm Müteferrika and Turkish Incunabula." Journal of the American Oriental Society 88, no. 3 (1968): 435-41. 
Wisnovsky, Robert. "The Nature and Scope of Arabic Philosophical Commentary in Post-Classical (ca. 1100-1900 AD) Islamic Intellectual History." In Philosophy, Science and Exegesis in Greek, Arabic and Latin Commentaries, vol. 2, edited by Peter Adamson, Han Baltussen, and M.W.F. Stone, 149-91. London: Institute of Classical Studies, 2004.

al-Yāzijī, Nāṣīf. Faṣl al-khițāb fì lughat al-i'rāb. Beirut: n.p., 1836.

al-Yāzijīi, Nāṣîf. Kitāa faṣl al-khiṭāb fì lughat al-i'rāb. 2nd ed. Beirut: n.p., 1854. 